\title{
Sea ice volume variability and water temperature in the Greenland Sea
}

\author{
Valeria Selyuzhenok $^{1,2}$, Igor Bashmachnikov ${ }^{1,2}$, Robert Ricker $^{3}$, Anna Vesman $^{1,2,4}$, and Leonid Bobylev ${ }^{1}$ \\ ${ }^{1}$ Nansen International Environmental and Remote Sensing Centre, 14 Line V.O. 7, 199034 St. Petersburg, Russia \\ ${ }^{2}$ Department of Oceanography, St. Petersburg State University, 10 Line V.O. 33, 199034 St. Petersburg, Russia \\ ${ }^{3}$ Alfred-Wegener-Institut, Helmholtz-Zentrum für Polar- und Meeresforschung, \\ Klumannstr. 3d, 27570 Bremerhaven, Germany \\ ${ }^{4}$ Atmosphere-sea ice-ocean interaction department, Arctic and Antarctic Research Institute, \\ Bering Str. 38, 199397 St. Petersburg, Russia
}

Correspondence: Valeria Selyuzhenok (valeria.selyuzhenok@niersc.spb.ru)

Received: 22 May 2019 - Discussion started: 26 June 2019

Revised: 21 November 2019 - Accepted: 4 December 2019 - Published: 5 February 2020

\begin{abstract}
This study explores a link between the long-term variations in the integral sea ice volume (SIV) in the Greenland Sea and oceanic processes. Using the Pan-Arctic Ice Ocean Modeling and Assimilation System (PIOMAS, 19792016), we show that the increasing sea ice volume flux through Fram Strait goes in parallel with a decrease in SIV in the Greenland Sea. The overall SIV loss in the Greenland Sea is $113 \mathrm{~km}^{3}$ per decade, while the total SIV import through Fram Strait increases by $115 \mathrm{~km}^{3}$ per decade. An analysis of the ocean temperature and the mixed-layer depth (MLD) over the climatic mean area of the winter marginal sea ice zone (MIZ) revealed a doubling of the amount of the upperocean heat content available for the sea ice melt from 1993 to 2016. This increase alone can explain the SIV loss in the Greenland Sea over the 24-year study period, even when accounting for the increasing SIV flux from the Arctic. The increase in the oceanic heat content is found to be linked to an increase in temperature of the Atlantic Water along the main currents of the Nordic Seas, following an increase in the oceanic heat flux from the subtropical North Atlantic. We argue that the predominantly positive winter North Atlantic Oscillation (NAO) index during the 4 most recent decades, together with an intensification of the deep convection in the Greenland Sea, is responsible for the intensification of the cyclonic circulation pattern in the Nordic Seas, which results in the observed long-term variations in the SIV.
\end{abstract}

\section{Introduction}

The Greenland Sea is a key region of deep ocean convection (Marshall and Schott, 1999; Brakstad et al., 2019) and an inherent part of the Atlantic Meridional Overturning Circulation (AMOC) (Rhein et al., 2015; Buckley and Marshall, 2016). The intensity of convection is governed by buoyancy (heat and freshwater) fluxes at the ocean-atmosphere boundary, as well as oceanic buoyancy advection into the region. The freshwater is thought to play the principal role in longterm buoyancy balance of the upper Greenland Sea (Meincke et al., 1992; G. Alekseev et al., 2001). The positive local precipitation-evaporation exchange accounts for only $15 \%$ of the freshwater balance in the Nordic Seas. Approximately half of the fresh water anomaly in the Nordic Seas originates from the freshwater flux through Fram Strait, which forms by freshening of the upper ocean due to sea ice melt in the Arctic Ocean and by solid sea ice transport melting outside the Arctic Ocean (Serreze et al., 2006; Peterson et al., 2006; Glessmer et al., 2014).

The general surface circulation in the region is shown in Fig. 1a. The upper $500 \mathrm{~m}$ in the western Greenland Sea is formed by mixing the Polar Water (PW), with a temperature close to freezing and salinity from 33 to 34 , and the Atlantic Water (AW), with a temperature over $3{ }^{\circ} \mathrm{C}$ and salinity around 34.9, recirculating in the southern part of the Fram Strait (Moretskij and Popov, 1989; Langehaug and Falck, 2012; Jeansson et al., 2017). The maximum PW content is found in the upper $200 \mathrm{~m}$ of the Greenland shelf and quickly 
decreases in the off-shelf direction (Håvik et al., 2017). The AW is found below the PW. Its core is observed in the seaward branch of the East Greenland Current (EGC), trapped by the continental slope. The central part of the Greenland Sea represents a mixture of the AW and the PW with the Greenland Sea Intermediate Water (with a temperature of -0.4 to $-0.8^{\circ} \mathrm{C}$ and salinity of $\left.\sim 34.9\right)$. The core of the Greenland Sea Intermediate Water is found at $500-1000 \mathrm{~m}$. The Greenland Sea Deep Water (with a temperature of -0.8 to $-1.2{ }^{\circ} \mathrm{C}$ and salinity $\sim 34.9$ ) is found below $1000 \mathrm{~m}$. The latter two water masses are formed by advection of intermediate and deep water coming from the Arctic Eurasian basin through Fram Strait, mixed with the recirculating Atlantic Water by winter convection (Moretskij and Popov, 1989; Alekseev et al., 1989; Langehaug and Falck, 2012). The convection depth in the Greenland Sea often exceeds $1500 \mathrm{~m}$ (Wadhams et al., 2004; Latarius and Quadfasel, 2016; Bashmachnikov et al., 2019).

The sea ice conditions in the Greenland Sea are defined by sea ice import through Fram Strait and by local ice formation and melt. The Fram Strait sea ice area (Vinje and Finnekåsa, 1986; Kwok et al., 2004) and volume flux (Kwok et al., 2004; Ricker et al., 2018) are primarily controlled by variations in the sea ice drift, which, in turn, are driven by the large atmospheric circulation patterns. Most of the variability of the atmospheric circulation and drift patterns is captured by the phase of the Arctic Oscillation (AO) or of its regional counterpart - the North Atlantic Oscillation (NAO) (Marshall et al., 2001). The positive AO (or NAO) phase intensifies northerly winds that drive more intensive ice transport through Fram Strait (Kwok et al., 2004). There is a moderate correlation (0.62) between the NAO index (excluding extreme negative NAO events) and winter sea ice area flux through Fram Strait over 24 years of satellite observations (1978-2002) (Kwok et al., 2004). A higher correlation (0.70) between NAO index and winter sea ice volume flux (20102017) is reported by Ricker et al. (2018). It is also argued that the interannual variations in the sea ice area flux through Fram Strait even more strongly linked to the Arctic Dipole pattern, since it explains a higher fraction of the observed interannual variations in the sea ice area flux than either the AO or the NAO (Wu et al., 2006). The Arctic Dipole pattern is derived as the second sea level pressure EOF over the Arctic, which has two centers of action: over the Laptev and Kara seas and over the Canadian Archipelago. The pattern represents an important mechanism regulating the ice export through Fram Strait (Wu et al., 2006).

The sea ice production in the Greenland Sea takes place east of the shelf between 71 and $75^{\circ} \mathrm{N}$ and north of $75^{\circ} \mathrm{N}$ within the highly dynamic pack ice transported southwards along the Greenland coast. The latter fills in cracks and leads and can reach considerable thickness. The sea ice forming east of the shelf is mainly thin newly formed ice. The highest interannual variations in sea ice area is observed between 71 and $75^{\circ} \mathrm{N}$ (Germe et al., 2011). In the region that the Odden sea ice tongue was occasionally formed, a sea ice pattern extended eastwards from the east Greenland shelf northwest of Jan Mayen (Wadhams et al., 1996; Comiso et al., 2001). The regression of the first empirical orthogonal function (EOF) of the sea ice extent to sea level pressure shows a weak inverse relation with the NAO-like pattern with a correlation coefficient of -0.4 . During the negative NAO phase, a reduction of the northerly wind permits a more intensive westward Ekman drift of sea ice into the Greenland Sea interior, which favors formation of the large Odden tongue (Shuchman et al., 1998; Germe et al., 2011). The Odden tongue area shows a strong negative correlation with the air temperature $(-0.7)$ over Jan Mayen and with the local sea surface temperature $(-0.9)$ (Comiso et al., 2001). Having stronger correlations with water temperature, the negative correlation of the sea ice area with the air temperature might be an artifact, as both are oppositely affected by the oceanic heat release to the atmosphere (Germe et al., 2011).

The ocean clearly plays an important role in the sea ice formation and melt in the region. In particular, it is speculated that the oceanic convection in the region favors a more intensive warm water flux from the south, affecting the air temperature and the sea ice extent (Visbeck et al., 1995). However, presently there is a lack of investigation linking oceanic processes with the sea ice variability in the Greenland Sea (Comiso et al., 2001; Kern et al., 2010).

Both sea ice area flux through Fram Strait and local sea ice processes in the Greenland Sea show changes over recent decades. An overall reduction in sea ice extent has been observed in the region since 1979 (Moore et al., 2015; Onarheim et al., 2018). In particular, a reduction in winter sea ice area is observed in the region of Odden ice tongue formation since the 2000s (Rogers and Hung, 2008; Kern et al., 2010; Germe et al., 2011). Concurrently, an increase in the sea ice area flux through Fram Strait since 1979 was reported by Kwok et al. (2004) and Smedsrud et al. (2017). A combined time series of sea ice volume flux through Fram Strait (1990-1996 Vinje et al., 1998; 1991-1999 Kwok et al., 2004; and 2003-2008 Spreen et al., 2009) shows a shift towards lower fluxes in the early 2000s compared to the 1990s (Spreen et al., 2009). However, the later study of Ricker et al. (2018) revealed that the sea ice volume flux in 2010-2017 is similar to that in the 1990s. Due to different uncertainties in the data and different methodologies used in those studies, it is not possible to merge the results to get an uninterrupted dataset for the entire period from 1990 to 2017. Although individual studies do not reveal significant trends in the sea ice volume flux through Fram Strait, the overall tendency remains unknown.

In this paper we further explore a link between sea ice volume variability in the Greenland Sea and oceanic processes. The first objective is to estimate the sea ice mass balance in the Greenland Sea from local sea ice formation or melt and from sea ice advection in or out of the sea, respectively. We extend this analysis back to 1979 using the Pan-Arctic Ice 

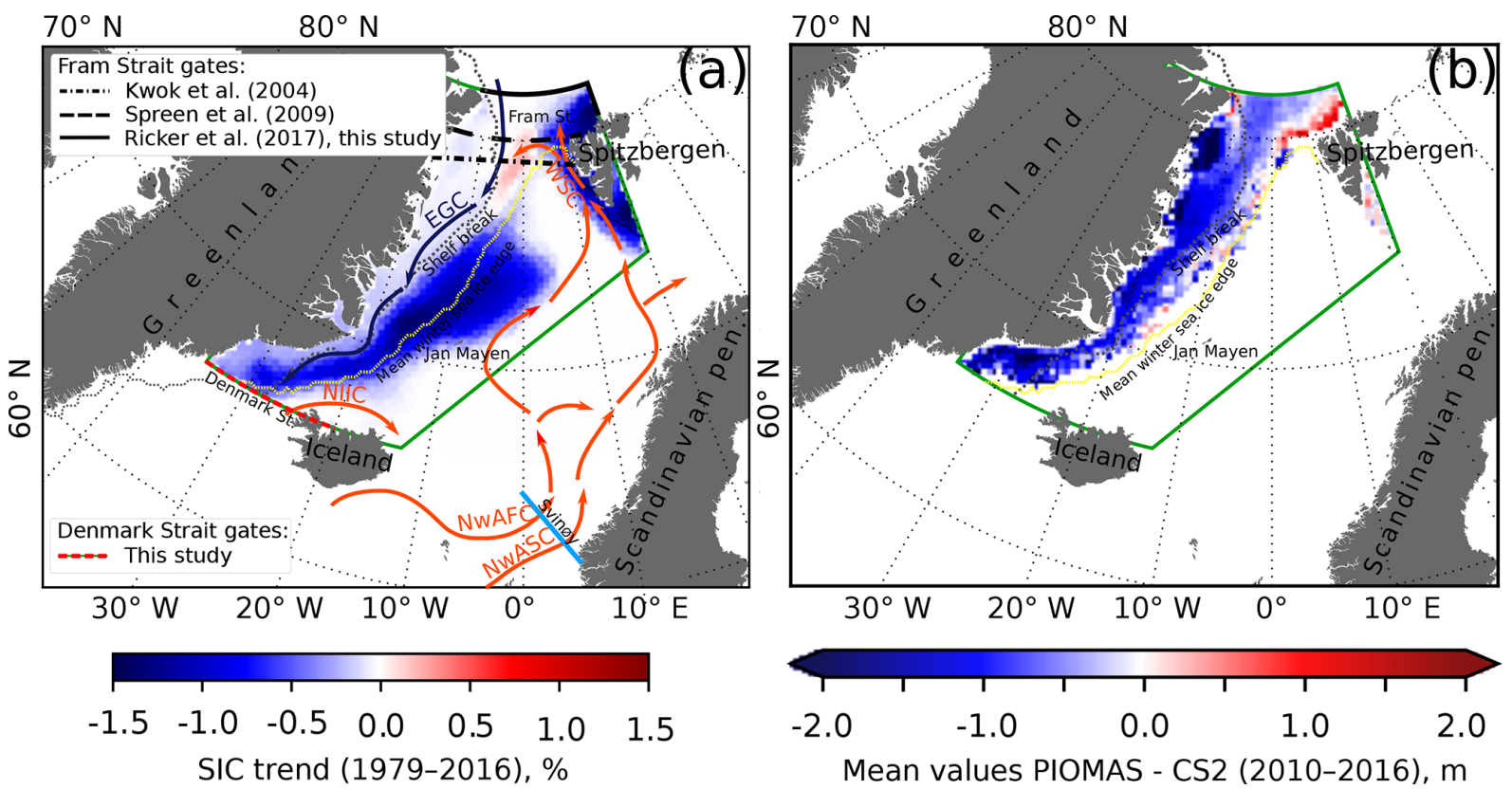

Figure 1. The study region is marked with the green box. (a) Linear trends in the mean October-April NSIDC sea ice concentration (SIC) over the period 1979-2016 (Comiso, 2015). The black lines show gates used for estimation of the sea ice volume flux through Fram Strait. Mean winter sea ice edge is shown with the dashed yellow line, and the shelf break (500 $\mathrm{m}$ isobath) is shown with the dashed gray line. EGC is the East Greenland Current, NIIC is the North Icelandic Irminger Current, NwAFC is the Norwegian Atlantic Front Current, NwASC is the Norwegian Atlantic Slope Current and WSC is the West Spitsbergen Current. (b) Mean difference between mean PIOMAS and CS2 effective sea ice thickness (m) for October-April 2010-2016.

Ocean Modeling and Assimilation System (PIOMAS) sea ice volume data. Further, we link the detected variations in sea ice mass balance to heat flux of the AW with the West Spitsbergen current (WSC) into the region.

\section{Data}

\subsection{PIOMAS sea ice volume}

PIOMAS (Pan-Arctic Ice Ocean Modeling and Assimilation System) is a coupled sea ice ocean model developed to simulate Arctic sea ice volume. It assimilates NSIDC (National Snow and Ice Data Center) near-real-time daily sea ice concentration, daily surface atmospheric forcing and sea surface temperature in the ice-free areas from NCEP (National Centers for Environmental Prediction) and NCAR (National Center for Atmospheric Research) reanalysis (Zhang and Rothrock, 2003; Schweiger et al., 2011). The PIOMAS provides monthly effective sea ice thickness (mean sea ice thickness over a grid cell) on a curvilinear model grid from 1978. A comparison of PIOMAS effective sea ice thickness with in situ, submarine and ICESat (Ice, Cloud, and land Elevation Satellite) data, mainly covering the western Arctic, showed that the PIOMAS uncertainty for monthly mean effective sea ice thickness does not exceed $0.78 \mathrm{~m}$ (Schweiger et al., 2011). The spatial pattern of PIOMAS ice thickness agrees well with those derived from in situ and satellite data. The model overestimates the thickness of thin ice and underestimates the thickness of thick ice. Such systematic differences might affect long-term trends in sea ice thickness and volume. There is an indication that the PIOMAS shows a conservative sea ice volume trend (1979-2010) (Schweiger et al., 2011).

Since PIOMAS performance has not been assessed south of the Fram Strait, the first part of this study is devoted to intercomparison of the PIOMAS sea ice thickness in the Greenland Sea with satellite data, as well as of the PIOMAS sea ice volume flux through Fram Strait with observationbased flux values known from literature (Sect. 4.1 and 4.2). The original monthly PIOMAS sea ice thickness data were gridded to $25 \mathrm{~km}$ EASE-2 grid. The PIOMAS data were further used to derive time series of monthly mean annual (September-August), mean winter (October-April) and mean summer (May-September) sea ice volume in the Greenland Sea for 1979-2016. The grid cell sea ice volume was computed as a product of PIOMAS effective sea ice thickness and the grid cell area.

\subsection{AWI Cryosat-2 sea ice thickness}

The PIOMAS effective sea ice thickness was intercompared against sea ice thickness from the Cryosat-2 satellite dataset (CS2, version 1.2, Ricker et al., 2014; Hendricks et al., 2016) 
for the Greenland Sea region (see green box in Fig. 1). The CS2 dataset provides monthly average sea ice thickness on an EASE-2 grid with a $25 \times 25 \mathrm{~km}$ spatial resolution from 2010 to 2017. Due to limitations of ice thickness retrieval from satellite altimetry, the CS2 dataset used was limited only to the cold season (October-April). The sea ice concentration data, provided along with CS2 thicknesses, was used to derive the effective sea ice thickness $\left(H_{\text {eff }}\right)$ for the comparison with the PIOMAS data. The conversion was performed for each grid cell:

$H_{\mathrm{eff}}=H \times C$,

where $H$ is CS2 sea ice thickness and $C$ is sea ice concentration.

Uncertainties in CS2 ice thickness increase below $78^{\circ} \mathrm{N}$ due to sparse orbit coverage (Ricker et al., 2014). The CS2 retrieval is based on sea ice freeboard measurements that are converted into sea ice thickness assuming hydrostatic equilibrium. Estimates of snow depth, required for the conversion, are based on the modified Warren climatology (Warren et al., 1999; Ricker et al., 2014). This climatology is not defined in the Fram Strait or Greenland Sea; therefore, snow depth estimates are extrapolated. Moreover, interannual variability in snow depth is not captured by the climatology, which can potentially cause biases in the final sea ice thickness retrieval. High drift speeds can also cause biases in the ice thickness retrieval due to the timing of satellite passes within 1 month. The typical uncertainty is in the range of $0.3-0.5 \mathrm{~m}$ but may potentially reach higher values.

\subsection{ARMOR dataset}

The long-term time series of water temperature at different depth levels and the mixed-layer depth (MLD) were derived from the ARMOR dataset (http://marine.copernicus.eu/, last access: 1 December 2019, 1993-2015). The dataset combines in situ temperature and salinity profiles with satellite observations and is constructed as follows. First, based on a joint analysis of the variations in satellite-derived anomalies (sea surface temperature and sea level from satellite altimetry) and of in situ thermohaline characteristics at different depths, linear multiple regressions are obtained. The regressions allow for extrapolating satellite data from the sea surface to standard oceanographic depth levels in a regular mesh of $0.25^{\circ} \times 0.25^{\circ}$, constructing the so-called "synthetic" vertical temperature and salinity profiles. The final monthly mean 3-D temperature and salinity distributions are obtained through optimal interpolation of all in situ observations for this month, together with the derived synthetic profiles, taken with different weights based on the inverse distance and type of measurement (in situ observations were given higher weights) (Guinehut et al., 2012). The number of in situ vertical temperature profiles in the marginal sea ice zone (MIZ) area of the Greenland Sea (Fig. 1) is very limited. Between 1993 and 2016, the number of casts varies from 13 to 350 per year, with a median of 90 casts per year. Even fewer profiles are obtained in the Greenland shelf, which is out of the scope of this study. In the ARMOR dataset, the use of satellite information provides a more precise and detailed picture of spatial and temporal variability of thermohaline characteristics than from interpolation of in situ profiles alone (as, for example, in the World Ocean Atlas dataset, https://www.nodc.noaa.gov/OC5/indprod.html, last access: 1 December 2019) and adds robustness to the results. The oceanic heat fluxes are estimated using currents from the ARMOR dataset with the same spatial and temporal resolution. The current velocities at various depth levels are obtained by extrapolating the sea surface current from satellite altimetry, downwards using the thermal wind relations. The vertical density profiles, used for the computations, are assessed from the previously obtained temperature and salinity profiles (Mulet et al., 2012).

\subsection{Long time series of water temperature of the West Spitsbergen Current}

Long-term monthly gridded water temperatures were obtained from "The Climatological Atlas of the Nordic Seas and Northern North Atlantic" (Korablev et al., 2007). The database merges together data ICES (International Counsel for Exploration of the Sea), from IMR (Institute of Marine Research), and from a number of international projects (ESOP, VEINS, TRACTOR, CONVECTION, etc.), as well as from Soviet Union era cruises in the study region. Since there are too few observations in the EGC before the 2000s, we use long-term temperature time series in the upper WSC (West Spitsbergen Current) at $78^{\circ} \mathrm{N}$, west of East Fjord (Fig. 1b), an area that is much better sampled. The depthaveraged water temperature at $100-200 \mathrm{~m}$ is used, as this layer is dominated by the AW and is not directly affected by heat exchange with the atmosphere year-round. This results in the highest temperature at these depths during the cold season. Even this region was sampled in a quite irregular manner, with a lower sampling frequency in winter. Since 1979 , the average number of samples was 161 per year, varying from, on average, 2-5 per year from November to May to 20-35 per year from June to October. The data gaps in the time series were filled in by kriging with a $30 \mathrm{~km}$ window. The interannual variations presented in this study were averaged over the months with the densest data coverage (JuneSeptember).

\section{Methods}

\subsection{Fram Strait and Denmark Strait sea ice volume flux from PIOMAS}

The sea ice volume flux through Fram Strait was calculated as a product of monthly average PIOMAS effective sea ice thickness, area of the grid cell and the sea ice drift veloc- 
ity (Ricker et al., 2018). The sea ice drift data were taken from the Polar Pathfinder Sea Ice Motion Vectors dataset (version 3), distributed by the National Snow and Ice Data Center (NSIDC) (Tschudi and Maslanik., 2016). The data are provided on EASE- 2 grid with a $25 \times 25 \mathrm{~km}$ spatial resolution. The gate was selected as a combination of a meridional section $\left(82^{\circ} \mathrm{N}\right.$ and $\left.12^{\circ} \mathrm{W}-20^{\circ} \mathrm{E}\right)$ and a zonal section (80.5$82^{\circ} \mathrm{N}$ and $20^{\circ} \mathrm{E}$ ), as suggested by Krumpen et al. (2016) (Fig. 1a). The location of the meridional gate at $82^{\circ} \mathrm{N}$ was chosen to reduce biases and errors in sea ice drift that become larger with increasing velocities south of the gate (Sumata et al., 2014, 2015). The meridional and zonal sea ice volume flux, $Q_{v}$ and $Q_{u}$ correspondingly, were computed as follows:

$Q_{v}=l / \cos (\lambda) \times H \times\left(D_{x} \times \sin (\lambda)-D_{y} \times \cos (\lambda)\right)$,

$Q_{u}=l / \cos (\lambda) \times H \times\left(D_{x} \times \cos (\lambda)-D_{y} \times \sin (\lambda)\right)$,

where $l=25 \mathrm{~km}$ is the distance between two data points, $H$ is the PIOMAS effective sea ice thickness, $D_{x}$ and $D_{y}$ represent sea ice drift velocity in the $x$ and $y$ directions of the grid, respectively, and $\lambda$ is the longitude of the respective grid cell.

The total sea ice volume flux through Fram Strait $(Q F$, positive into the Greenland Sea) was obtained as a sum of the meridional and zonal fluxes along the gate:

$Q F=Q_{u}+Q_{v}$.

The total sea ice volume flux through Fram Strait was derived for the period from 1979 to 2016 for each month. A similar methodology was used to assess the sea ice volume flux through Denmark Strait $(Q D)$ along the meridional section $\left(66^{\circ} \mathrm{N}\right.$ and $\left.35-20^{\circ} \mathrm{W}\right)$. The positive sign of $Q D$ corresponds to a sea ice volume outflow from the Greenland Sea.

In order to assess the data quality, the resultant sea ice volume fluxes through Fram Strait gate at $82^{\circ} \mathrm{N}$ were intercompared against available observation-based estimates in the Fram Strait (Kwok et al., 2004; Spreen et al., 2009; Ricker et al., 2018). The gate and the methodology used here were adopted from Ricker et al. (2018), while in the other two studies somewhat different methodologies and gate locations (Fig. 1a) were used. Each of the studies is also based on different datasets of sea ice concentration (SIC), thickness (SIT) and drift (SID) (Table 1).

\subsection{Greenland Sea sea ice mass balance}

In order to analyze the sea ice volume lost or gained due to local melt or freezing, we calculated the sea ice mass balance (MB) in the Greenland Sea. It was derived for each month from 1979 to 2016 as follows:

$M B=\left(V_{m}-V_{(m-1)}\right) \times t-\left(Q F_{m}-Q D_{m}\right) \times t$,

where $V_{m}$ and $V_{(m-1)}$ are regional sea ice volume of the current month ( $m$ th) and the previous month $\left((m-1)\right.$ th), $Q F_{m}$ and $Q D_{m}$ are Fram Strait and Denmark Strait sea ice volume flux of the current month ( $m$ th), and $t$ is a time period equal to 1 month. The regional sea ice volume was calculated for the area limited by 82 and $66^{\circ} \mathrm{N}$ latitudes and by the border in the east, shown in Fig. 1a (green box). We slightly extended the eastern boundary of the Greenland Sea to the southeast, compared to its classical definition, in order to include the entire area of the Odden ice tongue formation. The mass balance shows month-to-month increase or loss in sea ice volume within the Greenland Sea due to sea ice formation or melt. Positive MB values correspond to sea ice formation and negative values correspond to sea ice melt within the region. The monthly MB values were averaged over annual, winter and summer periods. Note that, due to averaging, negative annual values (sea ice volume loss, Fig. 4) can occur due to both an increase in sea ice melt and a decrease in sea ice formation.

\subsection{Mixed-layer depth (MLD) and marginal ice zone (MIZ) ocean temperature}

The MLD was derived using vertical profiles from the ARMOR dataset via the method of Dukhovskoy (Bashmachnikov et al., 2018, 2019). The method is similar to that used by Pickart et al. (2002) but is applied to the vertical profiles of the potential density gradients. Before processing, the smallscale noise in the potential density profiles was filtered out with $10 \mathrm{~m}$ sliding means. The gravitationally unstable segments were artificially mixed to neutral stratification. The MLD is defined as the depth where the vertical density gradient exceeds its two local standard deviations within a $50 \mathrm{~m}$ window, centered at the tested depth (see Bashmachnikov et al., 2018). The visual control shows that the results are mostly similar to the widely used methods by de Boyer Montégut et al. (2004) and Kara et al. (2003), except for weakly stratified areas where the Dukhovskoy's method defines the MLD with higher accuracy. The obtained mean distribution of the MLD and seasonal and interannual variations in the MLD in the central Greenland Sea are consistent with observations (Våge et al., 2015; Latarius and Quadfasel, 2016; Brakstad et al., 2019). All the results show an increase in the convection depth from the mid-1990s to the 2000s. There are some minor differences in the absolute values of MLD that arise from the use of different datasets (e.g., Latarius and Quadfasel, 2016 used only Argo floats) and methodologies for MLD detection. These minor differences have not broken the tendency of the maximum winter MLD to increase since the mid-1990s.

The position of the real MIZ strongly varies in time and along the EGC, being a function of local direction and intensity of sea ice transport by wind and current, variation in the characteristics of ice transport from the Arctic, interaction of ice floes, local ice thermodynamics, etc. Presence of melting sea ice, in turn, affects the upper-ocean and air temperatures. A warmer winter ocean warms up the air, which can further be advected over the sea ice causing its melt away 
Table 1. The list of data sources used for estimates of sea ice volume flux through Fram Strait: sea ice concentrations (SIC), sea ice thicknesses (SIT), sea ice drift velocities (SID) and the time periods of the estimates.

\begin{tabular}{llllr}
\hline Study & SIC & SIT & SID & Period \\
\hline Kwok et al. (2004) & ULS moorings & ULS moorings & Kwok and Rothrock (1999) & $1991-2002$ \\
Spreen et al. (2009) & ASI AMSR-E & ICESat & IFREMER & $2003-2008$ \\
Ricker et al. (2018) & OSI SAF SIC + sea ice type product & AWI Cryosat-2 & OSI SAF & $2010-2017$ \\
this study & - & PIOMAS & NSIDC Pathfinder v3 & $1979-2017$ \\
\hline
\end{tabular}

from the sea ice edge. Furthermore, an anomalously warmer ocean may prevent (or delay) formation of new ice. All these factors certainly affect the MIZ position. However, if we estimate ocean temperature variations only along the actual MIZ, we do not account for these effects. The considerations above show that defining the oceanic region directly and indirectly affecting the sea ice volume are not straightforward. In this study we examine interannual variations in ocean temperature in a fixed region, which is defined as an area enclosed between the $500 \mathrm{~m}$ isobath, marking the Greenland shelf break, and the mean winter location of the sea ice edge (Fig. 1). Using the fixed region also assures compatibility of interannual temperature variations. For the computations, the sea ice edge was defined as the $15 \%$ mean winter NSIDC sea ice concentration for 1979-2016. For brevity, we further, somewhat deliberately, call this region the MIZ area. Further, we will see that temperature trends remain positive and of the same order of magnitude all over the western Greenland Sea, except for a few limited areas along the shelf break. This assures the robustness of the results regarding the choice of the study region.

\subsection{Oceanic horizontal heat flux}

The ARMOR data were used to derive a time series of oceanic heat flux into the Nordic Seas. Total oceanic heat flux through the Svinøy transect $\left(Q_{\text {Svinøy }}\right)$ is calculated by integrating the heat flux values in the grid points:

$Q_{\text {Svinøy }}=\iint\left[\rho \times c_{p}\left(T-T_{\text {ref }}\right) \times v\right] d_{x} d_{z}$,

where $\rho=1030 \mathrm{~kg} \mathrm{~m}^{-3}$ is the mean sea water density, $c_{p}=$ $3900 \mathrm{~J} \mathrm{~kg} \mathrm{~g}^{-1}{ }^{\circ} \mathrm{C}^{-1}$ is specific heat of sea water, $T$ is sea water temperature, $T_{\text {ref }}=-1.8^{\circ} \mathrm{C}$ is the "reference temperature" and $v$ is current velocity perpendicular to the transect. The reference temperature was set to sea ice melt temperature in order to investigate the contribution of ocean heat fluxes to sea ice melt.

\section{Results}

\subsection{Assessment of PIOMAS-derived ice volume flux through Fram Strait and sea ice volume in the Greenland Sea}

In order to assess the quality of the PIOMAS data, monthly effective sea ice thickness in the Greenland Sea was compared to that derived using the CS2 dataset (Fig. 2). In general, PIOMAS underestimates effective sea ice thickness compared to CS2 (Fig. 1b). The mean difference between PIOMAS and CS2 grid cell values is $-0.70 \mathrm{~m}$. There are only two locations where PIOMAS shows thicker ice compared to CS2 north of Spitsbergen and along the sea ice edge. On the other hand, CS2 also tends to overestimate sea ice thickness in the marginal ice zone (Ricker et al., 2017). The highest absolute differences between the datasets are attributed to the areas along the Greenland coast (dark blue) and north of Spitsbergen (dark red) (Fig. 1b). The monthly scatter plots (Fig. 2a-g) show that PIOMAS tends to overestimate thin sea ice and underestimate thick sea ice thickness, which is in agreement with the tendency reported for the central Arctic (Schweiger et al., 2011). This results in moderate correlations between the two datasets $(0.63<r<0.77)$ for all winter months. The major discrepancies correspond to sea ice of $3 \mathrm{~m}$ and higher thickness, which form "tails" to the lowerright corner of the scatter plots (Fig. 2a-g).

PIOMAS sea ice volume flux through Fram Strait (October to April) was cross-compared with the fluxes derived using observation-based sea ice thickness data (see Table 1). The analysis shows that PIOMAS-based sea ice volume flux is in good agreement with the estimates from other datasets (Fig. 3, Table 2). The correlation coefficients between the three datasets and PIOMAS are over 0.6. The highest correlation of over 0.8, with the Ricker et al. (2018) data, can be explained by using identical gates and methodology for estimating ice volume fluxes (Fig. 1a). However, other statistical criteria (bias; relative percentage difference, RPD; and root-mean-square error, RMSE; see Table 2) indicate a somewhat stronger mismatch between the PIOMAS and Ricker et al. (2018) estimates compared to those between PIOMAS and Kwok et al. (2004) or Spreen et al. (2009). The possible sources of this discrepancy are discussed in Sect. 5. Overall, PIOMAS shows lower sea ice volume fluxes compared to the observation-based estimates (Fig. 3c). The inter- 

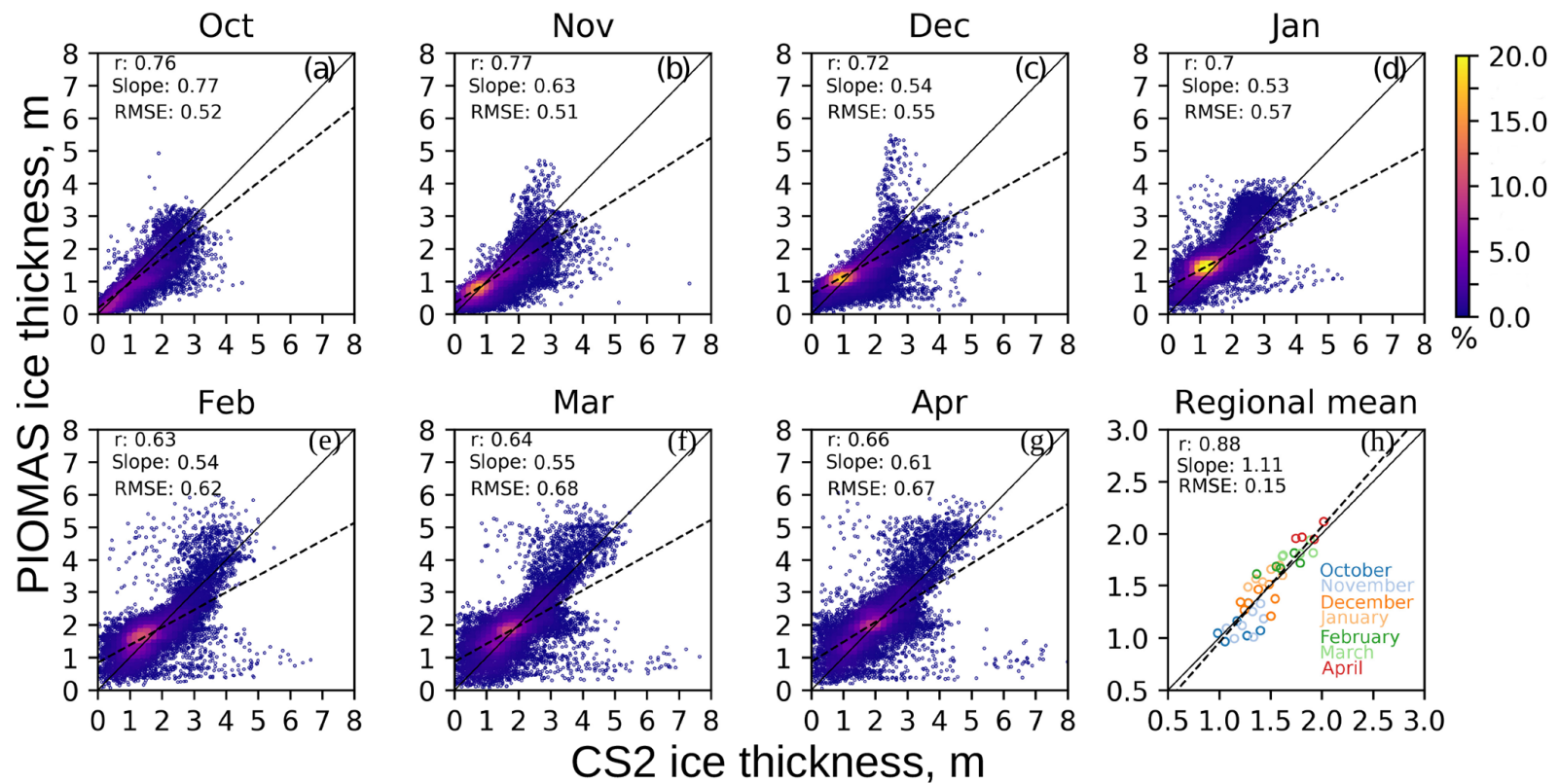

Figure 2. Density scatter plots of PIOMAS and CS2 monthly effective sea ice thickness (m) in the Greenland Sea, October-April 20102016: (a-g) each point corresponds to one grid cell of sea ice thickness. (h) Mean monthly sea ice thickness over the ice-covered area of the Greenland Sea for all intercompared snapshots. The colors of the points in panel (h) correspond to a month. The dashed lines show the linear regression fit and the solid lines are $45^{\circ}$ angles. The correlation coefficients $(r)$, the slope of the linear regressions and the root-mean-square error (RMSE) are given in the upper-left corner.

annual variations in the PIOMAS monthly and total winter sea ice volume flux agree well with other datasets (Fig. 3a; Table 2). At intra-annual timescales all three datasets show similar patterns with the minimum flux in October and maximum flux in March (Fig. 3b). Overall, moderate to high correlation between the datasets, low relative variance and low bias (Table 2) suggest that PIOMAS provides a realistic estimate of seasonal and interannual variations in the winter sea ice volume flux through Fram Strait. Figures $2 \mathrm{~h}$ and $3 \mathrm{c}$ suggest that PIOMAS correctly captures year-to-year variations in the mean effective sea ice thickness in the Greenland Sea and Fram Strait sea ice volume flux. This justifies using PIOMAS for analyzing interannual variations in the integral sea ice volume over the Greenland Sea.

\subsection{Interannual variations in sea ice flux through Fram Strait and sea ice volume in the Greenland Sea}

The sea ice volume in the Greenland Sea derived from PIOMAS revealed statistically significant (at $99 \%$ confidence level) negative trends in monthly winter, summer and annual values (Fig. 4a, Table 3). The strongest negative trend of $84.8 \mathrm{~km}^{3}$ per decade, or $13.5 \%$ of the long-term monthly annual mean volume, is observed in winter, while for summer months the trend was $58.2 \mathrm{~km}^{3}$ per decade or $9.3 \%$ of long-term annual mean volume. The sea ice volume in the Greenland Sea shows an overall reduction by $72.4 \mathrm{~km}^{3}$, or $11.5 \%$ of its long-term mean per decade.
The reduction of the sea ice volume in the Greenland Sea coincides with an increased sea ice volume import through Fram Strait by $9.6 \mathrm{~km}^{3}$ per decade or $8.8 \%$ of its long-term mean (significant at $90 \%$ confidence level). Thus, the total increase in the sea ice volume imported to the Greenland Sea through Fram Strait is $115.2 \mathrm{~km}^{3}$ per decade, which accounts for $18.2 \%$ of the Greenland Sea annual mean sea ice volume. The sea ice volume flux through Denmark Strait comprises about $2 \%$ (Fig. 3) of that through Fram Strait and shows no significant tendency. This flux has no considerable effect on the sea ice mass balance of the Greenland Sea.

A balance between sea ice volume import and export to the Greenland Sea through the straits and regional changes in the sea ice volume shows the volume of sea ice formed or lost due to thermodynamic processes within the region (Sect. 3.2). The sea ice mass balance in the Greenland Sea, expressed in sea ice volume loss, is shown in Fig. 4b. For about half of the years during the study period, sea ice volume loss in summer is higher than that in winter. However, there are a few years $(1992,1994,2004-2007)$ when winter sea ice volume loss significantly exceeds the summer one. During these years an increased sea ice volume flux thought the Fram Strait is detected (Fig. 4c). There is a positive statistically significant trend in annual and summer monthly mean sea ice volume loss, while the winter trend shows low statistical significance (Table 3). Overall, the monthly Greenland Sea sea ice volume loss increases by $9.4 \mathrm{~km}^{3}$ per decade (Fig. 4, Table 3). 
Table 2. Statistics of monthly PIOMAS versus satellite-based estimates of the sea ice volume fluxes through Fram Strait: Pearson correlation coefficient (cor. coef.), variance relative to PIOMAS (var. rel.), bias, relative percentage difference (RPD), and root-mean-square error (RMSE).

\begin{tabular}{lrrrrrr}
\hline Study & cor. coef. & mean slope & var. rel. (\%) & bias $^{\text {b }}$ & RPD (\%) & ${\text { RMSE }\left(\mathrm{km}^{3}\right)}^{\text {R }}$ \\
\hline Kwok et al. (2004) & 0.70 & 0.71 & 98 & 47 & 66 & 75 \\
Spreen et al. (2009) & 0.60 & 0.61 & 97 & 33 & 45 & 56 \\
Ricker et al. (2018) & 0.84 & 0.66 & 162 & 107 & 88 & 108 \\
\hline
\end{tabular}

${ }^{a}$ var. rel. $(\%)=\left(100 \% \cdot\right.$ var $\left._{\text {obs }}\right) /$ var PIOMAS. $^{b}$ bias $=$ obs. - PIOMAS.
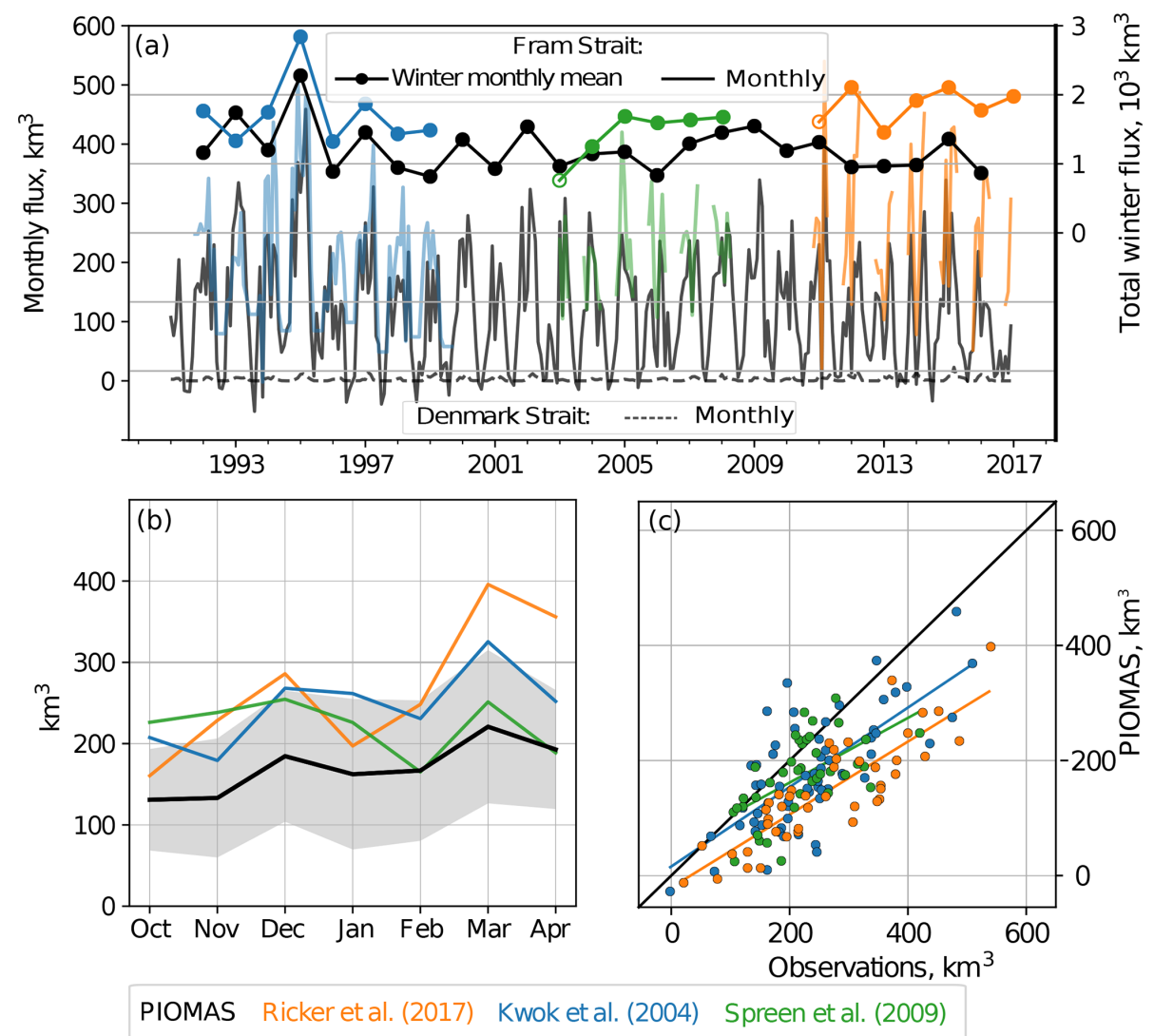

Figure 3. Sea ice volume fluxes $\left(\mathrm{km}^{3}\right)$ : (a) time series of PIOMAS and observation-based monthly sea ice volume fluxes through Fram and the Denmark Straits, 1991-2016 (note that the total winter fluxes are referenced to the right $y$ axis). Empty circles indicate seasons with an incomplete winter cycle. (b) Winter intra-annual cycle sea ice volume flux through Fram Strait, averaged over the period of the observations and over 1991-2016 for PIOMAS dataset. The gray background color corresponds to a single standard deviation interval from the PIOMAS mean. (c) Scatter diagram of monthly mean PIOMAS sea ice volume fluxes through Fram Strait versus monthly mean observations.

\subsection{Interannual variations in water temperature and MLD in the MIZ of the Greenland Sea}

In order to find the reason for the opposite trends in the sea ice volume of the Greenland Sea and the sea ice volume flux through Fram Strait, we investigate water temperature in the study region (Sects. 2.3, 3.3, 3.4). A relatively warm AW is observed in the East Greenland Current (EGC), off the Greenland shelf break, below a thin upper mixed layer dominated by the cold PW. Our estimates of winter MLD show that the AW should be regularly brought to the ocean surface by vertical winter mixing, which is consistent with observations (Håvik et al., 2017; Våge et al., 2018). The presence of the AW is observed in the climatology, as water temperature (and salinity) in the EGC increases with depth, from about $0{ }^{\circ} \mathrm{C}$ near the sea surface to $2-4^{\circ} \mathrm{C}$ at $500 \mathrm{~m}$. In the 24 -year means, the northern temperature maximum (Fig. 5a) results from recirculation of AW of the WSC in the southern Fram Strait, while the southern maximum is due to the northwards heat flux with the North Icelandic Irminger Current (NIIC) 
Table 3. Trends in monthly mean characteristics in the Greenland Sea calculated over annual (September-August), winter (October-April) and summer (May-September) periods: sea ice volume ( $\mathrm{SIV}, \mathrm{km}^{3} \mathrm{yr}^{-1}$ ), sea ice volume loss (SIV loss, $\mathrm{km}^{3} \mathrm{yr}^{-1}$ ), sea ice flux through Fram Strait (SIF Fram, $\mathrm{km}^{3}$ year $\left.{ }^{-1}\right)$, water temperature in MIZ $\left(T_{\mathrm{W}},{ }^{\circ} \mathrm{C} \mathrm{yr}^{-1}\right)$ and in the West Spitsbergen Current (TWSC, $\left.{ }^{\circ} \mathrm{C} \mathrm{yr}{ }^{-1}\right)$, and heat flux across the Svinøy section $\left(Q_{\text {Svinøy }}, \mathrm{TW} \mathrm{yr}^{-1}\right) . r^{2}$ is the coefficient of determination, SD is the standard deviation (m) and $p$ value is the probability value.

\begin{tabular}{|c|c|c|c|c|c|}
\hline Parameter & Season & Trend & $r^{2}$ & SD & $p$ value \\
\hline \multirow{3}{*}{ SIV, $\mathrm{km}^{3} \mathrm{yr}^{-1}$} & annual & $-7.24(-1.15 \%)$ & 0.42 & 1.48 & $<0.01$ \\
\hline & winter & $-8.48(-1.35 \%)$ & 0.44 & 1.66 & $<0.01$ \\
\hline & summer & $-5.82(-0.93 \%)$ & 0.26 & 1.72 & $<0.01$ \\
\hline \multirow{3}{*}{ SIV loss, $\mathrm{km}^{3} \mathrm{yr}^{-1}$} & annual & $0.94(0.88 \%)$ & 0.09 & 0.52 & 0.08 \\
\hline & winter & $1.18(1.10 \%)$ & 0.06 & 0.83 & 0.17 \\
\hline & summer & $0.84(0.79 \%)$ & 0.10 & 0.45 & 0.07 \\
\hline \multirow{3}{*}{ SIF Fram, $\mathrm{km}^{3}$ month $^{-1} \mathrm{yr}^{-1}$} & annual & $0.96(0.88 \%)$ & 0.09 & 0.53 & 0.08 \\
\hline & winter & $1.36(1.25 \%)$ & 0.08 & 0.82 & 0.10 \\
\hline & summer & $0.56(0.52 \%)$ & 0.09 & 0.32 & 0.08 \\
\hline \multirow{3}{*}{$T_{\mathrm{W}},{ }^{\circ} \mathrm{C} \mathrm{yr}^{-1}$} & annual & $0.015(1.50 \%)$ & 0.23 & 0.007 & 0.04 \\
\hline & winter & $0.008(0.01 \%)$ & 0.05 & 0.007 & 0.29 \\
\hline & summer & $0.026(3.00 \%)$ & 0.29 & 0.008 & $<0.01$ \\
\hline \multirow{3}{*}{$Q_{\text {Svinøy }}, \mathrm{TW} \mathrm{yr}^{-1}$} & annual & $1.84(1.39 \%)$ & 0.48 & 0.41 & $<0.01$ \\
\hline & winter & $1.83(1.38 \%)$ & 0.35 & 0.54 & $<0.01$ \\
\hline & summer & $1.82(1.37 \%)$ & 0.36 & 0.53 & $<0.01$ \\
\hline$T_{\mathrm{WSC}},{ }^{\circ} \mathrm{C} \mathrm{yr}^{-1}$ & annual & $0.036(0.60 \%)$ & 0.30 & 0.30 & $<0.01$ \\
\hline
\end{tabular}

through Denmark Strait (Hansen et al., 2008; Ypma et al., 2019). The latter is a northern branch of the Irminger Current. The sea ice is affected by the heat in the upper mixed layer, the depth of which varies on synoptic, seasonal and interannual timescales. Our analysis shows that the obtained tendencies of increase in water temperature with time, derived in the next paragraphs, are largely independent of the choice of the water layer, at least within the upper $200 \mathrm{~m}$ of the water column. In further analysis we present results for the upper $50 \mathrm{~m}$ layer (the typical summer mixed layer in the MIZ) and the upper $200 \mathrm{~m}$ layer (the typical winter mixed layer in the MIZ, Fig. 6c). In the annual means, the water temperature, averaged over upper $50 \mathrm{~m}$ layer of the MIZ, has a maximum of $2{ }^{\circ} \mathrm{C}$ in September and decreases to $0.1-$ $0.2^{\circ} \mathrm{C}$ in March-April. Averaged over the upper $200 \mathrm{~m}$, the patterns of the mean distribution and of (somewhat weaker) tendencies in temperature and salinity closely repeat those in Fig. 5. When averaged over the fixed region, corresponding to the mean winter MIZ area (Fig. 1), the mixed-layer seawater temperature is always above the freezing point; i.e., overall, the ocean melts sea ice in this area year-round.

Figure 5a shows interannual variations in November $2{ }^{\circ} \mathrm{C}$ sea water isotherm (averaged over the upper $200 \mathrm{~m}$ layer). Water temperature in November reflects the heat fluxes accumulated during the warm period. It shows the background conditions at the beginning of the winter cooling, when sea ice start forming locally. From the 1990s to the 2000s, the $2{ }^{\circ} \mathrm{C}$ isotherm approached the shelf break. The largest westward propagation is observed in the WSC recirculation area $\left(76-78^{\circ} \mathrm{N}\right)$ and northwest of Jan Mayen $\left(70-73^{\circ} \mathrm{N}\right)$, in the southern Odden tongue region. The tendency of the isotherm to approach the shelf break is consistent for different isotherms (from 1 to $3^{\circ} \mathrm{C}$ ), for different layer thicknesses (50-200 m) and for different months. Only for winter months, when the whole upper $200 \mathrm{~m}$ mixed layer effectively releases heat to the atmosphere, do the interannual trends become insignificant. The linear temperature trend (Fig. 5b) shows warming in the whole area of the eastern MIZ. The strongest warming follows the pathway of the recirculating AW in the northern Greenland Sea (Glessmer et al., 2014; Håvik et al., 2017), which is known to strongly affect the central regions of the sea (Rudels et al., 2002; Jeansson et al., 2008). The warming in the northern Greenland Sea is linked to a strong warming of the WSC and the Norwegian Atlantic Front Current (NwAFC), while that in the southernmost part of the sea is linked with the NIIC. Two exceptions can be noted: the northwestern part of the coastally trapped EGC (where negative trends are obtained in the area dominated by a colder PW outflow from the Arctic) and the area of the EGC recirculation into the Greenland Sea at $72-74^{\circ} \mathrm{N}$ extended from the continental shelf break to $8-9^{\circ} \mathrm{W}$ (here the tendencies in the upper-ocean temperature are close to zero). The latter is the area where the Odden ice tongue starts spreading into the Greenland Sea interior (Germe et al., 2011). The decreasing temperature in both of these areas is consistent 

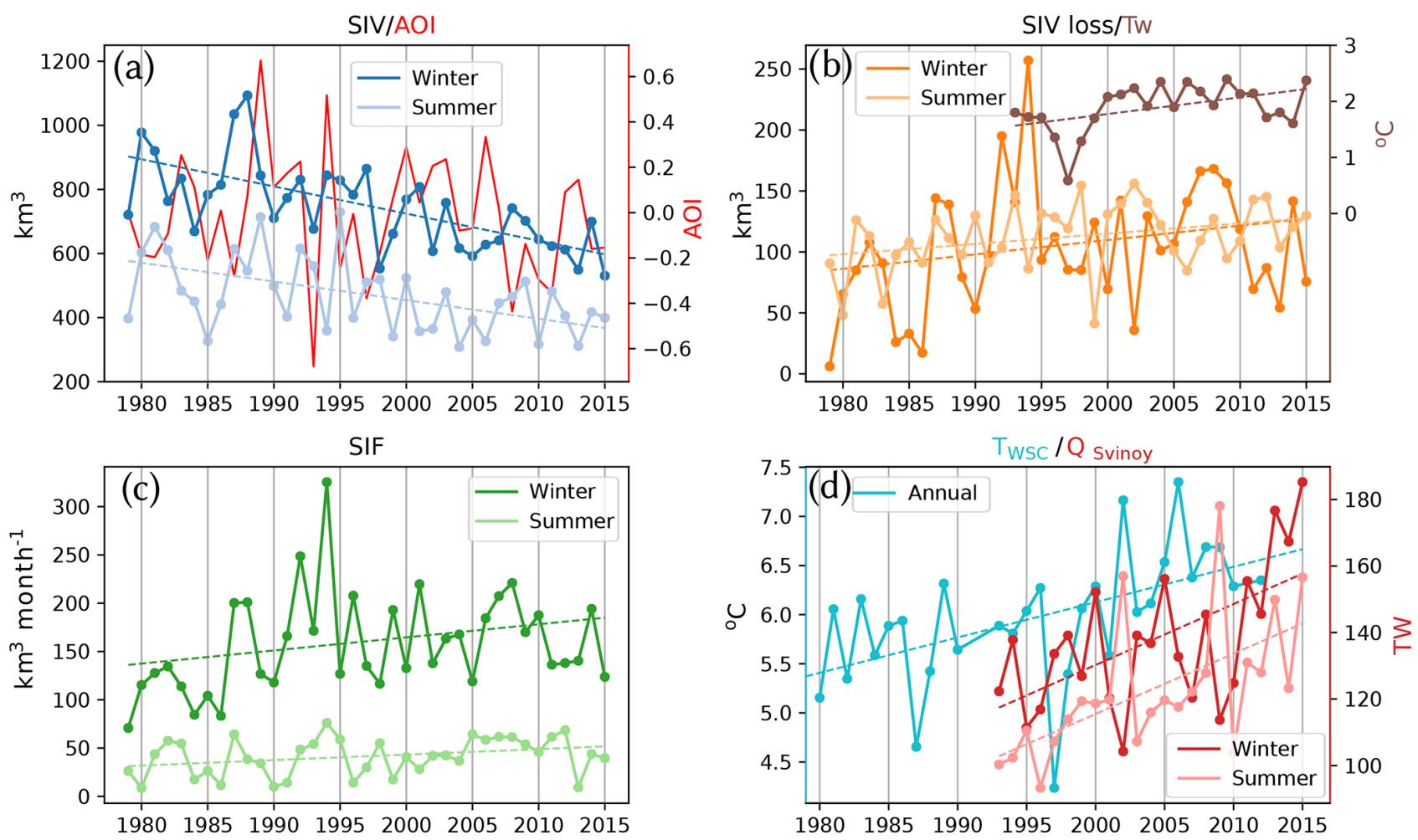

Figure 4. Time series of winter (December-April) and summer (May-November) and annual ice ocean atmosphere characteristics in the Greenland Sea: (a) monthly mean PIOMAS sea ice volume (SIV, $\mathrm{km}^{3}$ ) and monthly summer AO index (AOI), (b) monthly mean PIOMAS sea ice volume loss (SIV loss, $\mathrm{km}^{3}$ ) and mean September water temperature in MIZ $\left(T \mathrm{w},{ }^{\circ} \mathrm{C}\right)$, (c) monthly mean sea ice volume flux through Fram Strait (SIF, $\mathrm{km}^{3}$ month $\left.^{-1}\right)$, and (d) annual mean water temperature in the West Spitsbergen Current $\left(T_{\mathrm{WSC}}\right.$, $\left.{ }^{\circ} \mathrm{C}\right)$ and monthly mean ocean heat flux $\left(Q_{\text {Svinøy }}, T W\right)$ through Svinøy section (see Fig. 1).

with a stronger sea ice and PW transport from the Arctic (Sect. 4.2).

With a stronger melting of sea ice at the seawards part of the MIZ, together with the ice volume loss, we should observe a sea ice area loss. This is consistent with Germe et al. (2011). In particular, the positive water temperature trend over the eastern part of the Odden region suggests an overall decrease in the Odden formation by the end of the study period. The mean temperature trend over the Odden region (the area within the dotted line in Fig. 5b) is $0.08^{\circ} \mathrm{C}$ per year, i.e., there is an area-mean increase of $1.8^{\circ} \mathrm{C}$ from 1993 to 2016. This exceeds the mean ocean temperature increase, averaged in the MIZ area (Eq. 7), which includes the northern shelf break regions with negative temperature trends. Therefore, the estimates of the heat available for the ice melt, based on the values presented in Eq.(7), should be considered the lower limit of the heat release within the Odden region.

Interannual variations in water characteristics, averaged over the upper $200 \mathrm{~m}$ and in the MIZ area, are shown in Fig. 6. From 1993, an overall increase in annual mean temperature in the MIZ is observed, suggesting an increasing intensity of the sea ice melt. The temperature increases during all seasons, but the strongest increase is detected in autumn (by 0.5 and $0.6^{\circ} \mathrm{C}$ over the 24 years). The winter convection efficiently uplifts heat to the sea surface. The heat accumulated in summer is mostly released during winter. Figure $4 \mathrm{~d}$ suggests that the results can be extrapolated back to at least 1980 , as the slope of the trend lines in temperature of the advected AW for 1980-1992 is practically the same as for the period discussed above. We observe a growing difference between September and March temperatures (Fig. 6a), together with a decrease in interannual temperature trend to become insignificant in winter. The growing difference in temperature is observed in spite of the equal winter and summer trends in the heat inflow with the NwASC (see $T_{\mathrm{w}}$ and $Q_{\text {Svinøy }}$ in Table 3). Therefore, in the MIZ region, all additional heat accumulated in the upper $200 \mathrm{~m}$ layer during summer is uplifted to the sea surface by winter convection, preventing ice formation in the ice-free areas or melting the ice in the ice-covered ones.

In the MIZ, the autumn temperature increases, and the zonal thermal gradient across the MIZ increases by 1.7 times from 1993 in the annual mean (Fig. 6b) and by nearly 4 times in winter. This goes along with a decrease in the annual mean distance between the $2^{\circ} \mathrm{C}$ or $3^{\circ} \mathrm{C}$ isotherm and the shelf break (Fig. 6d): from $120 \mathrm{~km}$ in 1993 to $50 \mathrm{~km}$ in 2016 

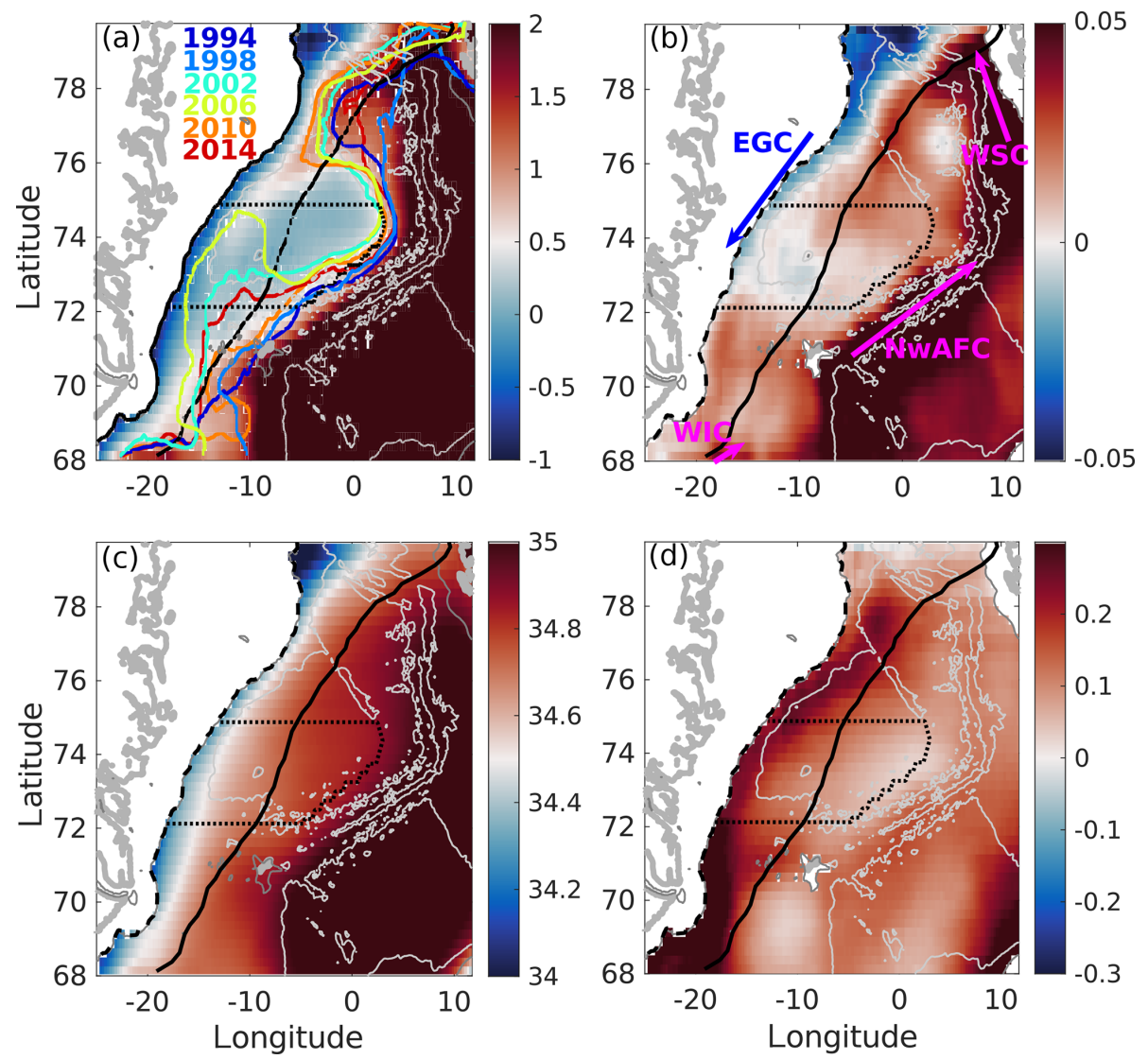

Figure 5. Marginal sea ice zone (enclosed in black lines) and thermohaline water properties averaged in the upper $50 \mathrm{~m}$ layer during the cold season (October-April). (a) Time-mean (1993-2016) temperature $\left({ }^{\circ} \mathrm{C}\right)$ in MIZ and location of $2{ }^{\circ} \mathrm{C}$ isotherm in November for selected years; (b) linear temperature trend $\left({ }^{\circ} \mathrm{C} \mathrm{yr}^{-1}\right)$ in the upper 50 m-layer from 1993 to 2016; (c) time-mean (1993-2016) salinity in MIZ; (d) linear salinity trend in the upper $50 \mathrm{~m}$ layer from 1993 to 2016. In panel (b), EGC is the East Greenland Current, NwAFC is the Norwegian Atlantic Front Current, NIIC is the North Icelandic Irminger Current and WSC is the West Spitsbergen Current. Dotted lines in panels (b) and (d) mark the region where Odden tongue is observed.

(see also Fig. 5a). The direct result of this is a faster melt of the sea ice episodically advected from the MIZ eastwards by EGC filaments and mesoscale eddies (Kwok, 2000; von Appen et al., 2018). These processes can transport sea ice dozens of kilometers eastward (von Appen et al., 2018). The most favorable conditions for eddy formation are observed during northerly winds. The eddies sweep sea ice and PW seawards and advect warm AW closer to the ice edge, resulting in increased bottom and lateral sea ice melt (Bondevik, 2011). However, a few episodic observations of the ice dynamics in the MIZ do not presently allow for quantifying the importance of this effect.

The 24-year mean winter mixed-layer depth (MLD) in the MIZ off the Greenland shelf varies from 120 to $250 \mathrm{~m}$, with the mean value around $150 \mathrm{~m}$, as derived from ARMOR dataset. Averaged over the MIZ, MLD increases from the mean value of $130 \mathrm{~m}$ in 1993 to around $180 \mathrm{~m}$ in 2016 (Fig. 6c). Since winter mixing does not reach the lower limit of the warm Atlantic water at 500-700 m, the deeper the mixing, the more heat is uplifted towards the sea surface, melt- ing the ice in the MIZ. The increase in MLD results from a higher upper-ocean density due to increasing salinity of the AW, tempered by the increasing temperature (Fig. 5b, d), which is consistent with the findings of Lauvset et al. (2018). Given the increase in ocean temperature in the upper $200 \mathrm{~m}$ layer in the MIZ from $1.3^{\circ} \mathrm{C}$ in September 1993 to $1.8^{\circ} \mathrm{C}$ in September 2016 together with an increase in the mean winter MLD from $130 \mathrm{~m}$ in 1993 to $180 \mathrm{~m}$ in 2016, we can make a rough estimate of the increase (over the 24 years) in the heat released by winter MLD in the MIZ:

$$
\begin{aligned}
\mathrm{d} Q & =\mathrm{d} Q_{2016}-\mathrm{d} Q_{1993}=c_{p} \times \rho_{\text {water }} \\
& \times(1.8 \times 180-1.3 \times 130) \times \text { MIZ area }
\end{aligned}
$$

where $c_{p}=3900 \mathrm{~J}^{\circ} \mathrm{C}^{-1} \mathrm{~kg}^{-1}, \rho_{\text {water }}=10^{30} \mathrm{~kg} \mathrm{~m}^{-3}$ and the MIZ area is estimated as $2.3 \times 10^{11} \mathrm{~m}^{2}$. The computations give an additional heat release of $1.5 \times 10^{20} \mathrm{~J}$, following the observed water temperature seasonal cycle, we assume that all the heat from the growing winter MLD is released at the sea surface. If all of this heat were to go towards melting the 

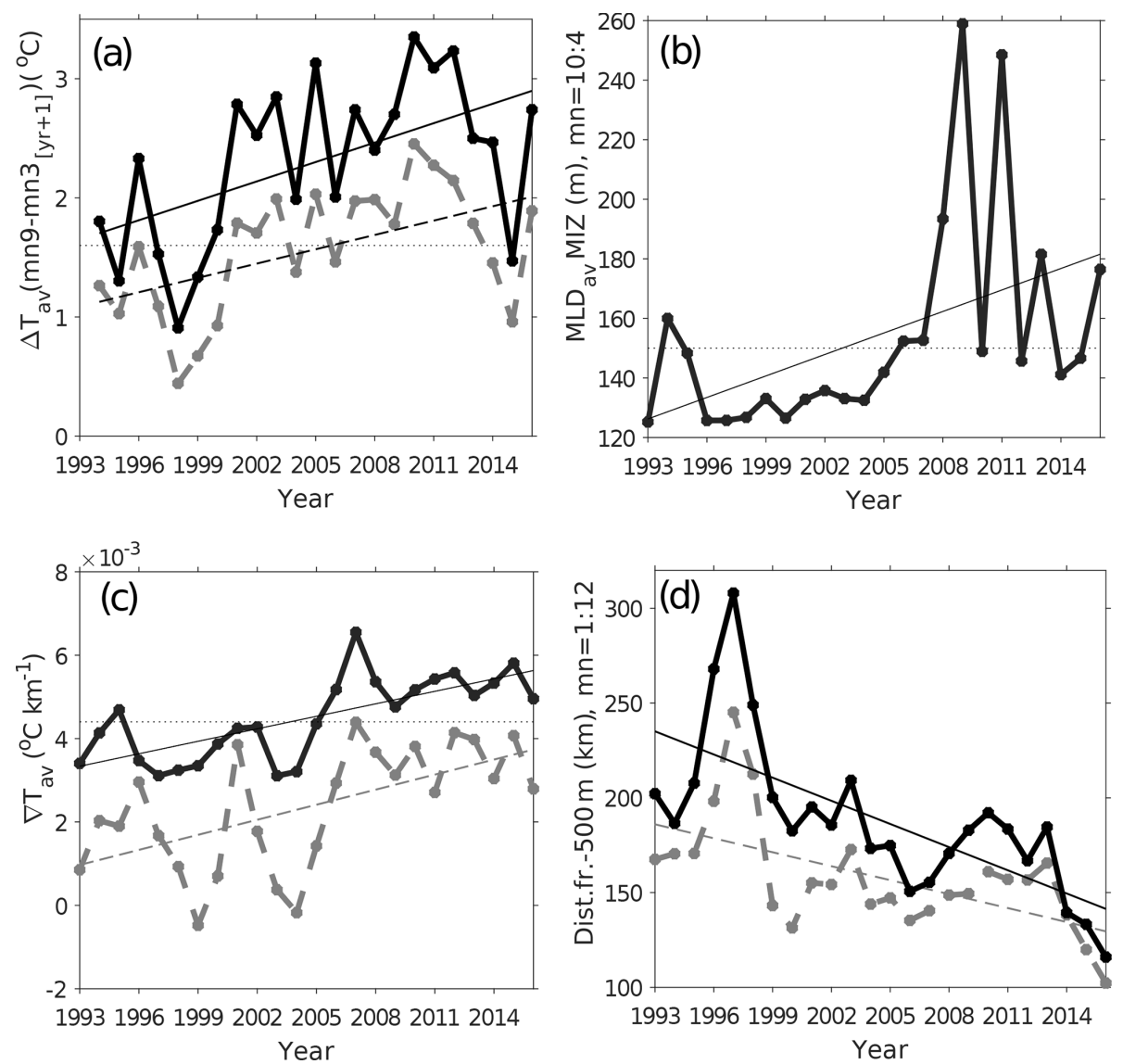

Figure 6. Interannual variations in water properties, averaged over the MIZ area. (a) Temperature drop $\left({ }^{\circ} \mathrm{C}\right)$ from maximum in September to minimum in April next year; (b) annual mean temperature gradient across the MIZ $\left({ }^{\circ} \mathrm{C} \mathrm{km}^{-} 1\right)$; (c) the mixed-layer depth (m), averaged over the cold season; (d) annual mean distance of the $3{ }^{\circ} \mathrm{C}$ isotherm from the shelf break $(\mathrm{km})$. In panels (a), (b) and (d) the solid black line is the data averaged over the upper $50 \mathrm{~m}$ layer and the dashed gray line is the data over the upper $200 \mathrm{~m}$ layer. In panel (d) $3^{\circ} \mathrm{C}$ isotherm is shown for the $50 \mathrm{~m}$ means and $2{ }^{\circ} \mathrm{C}$ isotherm for the $200 \mathrm{~m}$ means.

ice in the MIZ, we would get an increase in the winter sea ice volume loss:

$\mathrm{d} V=\mathrm{d} Q /\left(L \times \rho_{\text {ice }}\right) \approx 500 \mathrm{~km}^{3}$,

where the specific heat of ice fusion $L=3.3 \times 10^{5} \mathrm{~J} \mathrm{~kg}^{-1}$ and the ice density of $\rho_{\text {ice }}=920 \mathrm{~kg} \mathrm{~m}^{-3}$ (Petrich and Eicken, 2010). This far exceeds the observed sea ice volume loss in the region (SIV loss monthly winter trend $\times 12$ months $\times 24$ years $\approx 200 \mathrm{~km}^{-3}$ ). Certainly, not all heat released by the upper ocean in the MIZ area goes to the ice melt. An unknown fraction of heat is directly transferred to the atmosphere through open water, ice leads or is advected away from the MIZ area by ocean currents and eddies. The sea ice melt may additionally increase haline stratification at the lower boundary of the ice, preventing ocean heat from reaching the ice cover. However, the estimates above suggest that the autumn warming of the upper MIZ region, limited from below by the winter mixed layer, is able to release more than enough heat to account for the observed reduction of sea ice volume in the region.

\section{Discussion}

\subsection{PIOMAS-derived trends}

The revealed regional trends in sea ice volume rely on the PIOMAS model data. A comparison of interannual variations in PIOMAS regional sea ice thickness and the sea ice volume flux through Fram Strait showed that PIOMAS estimates are in agreement with the observation-based estimates during the recent decades. However, the PIOMAS systematic overestimation of thin ice and underestimation of thick ice thickness, reported for the central Arctic, affects the long-term volume trend (Schweiger et al., 2011). Schweiger et al. (2011) conclude that the PIOMAS-based volume trend is lower than the actual one. Given that similar systematic errors in effective sea ice thickness are found for the Greenland Sea (Fig. 2), it is likely that the derived Greenland Sea sea ice volume trend is underestimated. The PIOMAS Fram Strait sea ice volume flux can also be affected by these systematic errors. The model studies show three major positive peaks in 
the Fram Strait sea ice volume flux since 1979: 1981-1983, 1989-1990, 1994-1995 (Arfeuille et al., 2000; Lindsay and Zhang, 2005). The anomaly in 1989-1990 was caused by an increase in the thickness of the transported sea ice, while the anomaly in 1994-1995 was due to an intensification of southward sea ice drift (Arfeuille et al., 2000). The reduction of Arctic multiyear ice fraction during the late 1980s-early 1990s (Comiso, 2002; Rigor and Wallace, 2004; Yu et al., 2004; Maslanik et al., 2007) are in line with this finding. The sea ice volume flux through Fram Strait derived from PIOMAS shows the peaks in 1981-1985 and 1994-1995 but does not capture the anomaly of 1989-1990 (Fig. 4c). During this period there is no significant shift in the PIOMAS effective sea ice thicknesses in the Fram Strait, which is likely caused by the PIOMAS systematic errors that smoothed the differences in thickness between thick and thin ice. Since 1993, the PIOMAS Fram Strait sea ice volume flux correlates well with the observation-based fluxes (Fig. 3). The main sources of relative errors between the Fram Strait volume flux estimates can be related to the different choice of methodologies, datasets and gates used to derive sea ice volume fluxes (Table 1, Fig. 1). Lower PIOMAS-based sea ice volume flux can be attributed to the above-discussed general PIOMAS tendency to underestimate sea ice thickness. Figure $1 \mathrm{~b}$ shows that for the entire meridional $82^{\circ} \mathrm{N}$ gate, which is the main gate for sea ice import to the Greenland Sea, the PIOMAS effective sea ice thickness is lower compared to the CS2 effective thickness. In addition, the NSIDC sea ice drift shows lower speed compared to the OSI SAF drift used in Ricker et al. (2018). A combination of lower drift speed with thinner ice thickness might be the reason of the largest offset (Table 2, Fig. 3) between the PIOMAS-based Fram Strait sea ice volume fluxes and those derived in Ricker et al. (2018).

\subsection{Link to the variability of ocean temperature and atmospheric forcing}

The revealed decrease in sea ice volume in the Greenland Sea goes in parallel with an increase in the ice volume inflow through Fram Strait. As the sea ice volume flux through Denmark Strait does not show any significant change, this indicates a simultaneous intensification of the processes of ice melt and reduction in sea ice formation in the sea. The latter is supported by the highest negative trends in the sea ice area (Fig. 1, expressed in SIC trend) in the area of the Odden tongue between 73 and $77^{\circ} \mathrm{N}$.

The interannual variations in sea ice area were previously linked to variations in air temperature (Comiso et al., 2001). The results of our paper permitted us to speculate that ocean temperature may be important in controlling Odden formation (see also Shuchman et al., 1998; Germe et al., 2011). For example, the reduction of Odden tongue occurrence in the 2000s (Latarius and Quadfasel, 2010) might be partially driven by the increase in upper-ocean heat content (Fig. 5b).
The atmospheric heat convergence over the Greenland Sea is estimated as the sum of atmospheric heat fluxes across the northern, southern, eastern and western boundaries of the Greenland Sea (positive fluxes are in the study region), using ERA-Interim reanalysis. On average, from October to April of following year, we obtained always negative atmospheric heat convergence over the Greenland Sea (1000 to $900 \mathrm{GPa}$ ) of $-120 \mathrm{TW}$ on average, varying from -170 to $-90 \mathrm{TW}$. The sign is consistent with typical winter winds from the Arctic or Greenland (see, for example, Germe et al., 2011), being warmed while passing over the region. The negative atmospheric heat convergence is roughly balanced by the integral heat release from the ocean to the atmosphere over the same area on the order of $+130 \pm 40 \mathrm{TW}$, assuming the regional mean winter heat release by the ocean of $150 \pm 50 \mathrm{~W} \mathrm{~m}^{-2}$ (Moore et al., 2015).

The heat convergence has tendency to decrease in absolute value from 1993 to 2016 by about 4 TW, accompanied by a rise of the area-mean winter air temperature of about $1^{\circ} \mathrm{C}$. The oceanic southwards heat advection through $77.5^{\circ} \mathrm{N}$ in the upper $200 \mathrm{~m}$ layer increases by $1 \mathrm{TW}$. The source of the atmospheric warming possibly lies in the northwest, in the southeastern Fram Strait, a known region of high oceanic heat flux into the atmosphere (see, for example, Dukhovskoy et al., 2006).

We argue that at least the overall sea ice volume loss from 1993 to 2016 is governed by the ocean. The surplus of the amount of the heat, released by the ocean at the end of the study period, is more than twice of that necessary for bringing up the observed sea ice volume loss, even when accounting for the detected increase in the sea ice volume import through Fram Strait. Heat loss to the atmosphere and the neighboring ocean areas should take up the rest of the heat. In particular, the observed increase in ocean temperature over the Greenland Sea (Fig. 5b) may be a reason for a corresponding increase in the air temperature, used for explaining negative trends in the sea ice area (Comiso et al., 2001).

The observed trends are due to both the increase in temperature of the AW in the MIZ and an increase in winter MLD in the area, bringing more AW to the surface. A significant vertical extent of the warm subsurface AW layer, going down to 500-700 m depth (Håvik et al., 2017), results in a higher ocean heat release for a stronger mixing for the observed MLD in the MIZ. A similar mechanism was suggested for the Nansen Basin of the Arctic Ocean, where an enhanced vertical mixing through the pycnocline is thought to decrease the sea ice area in the basin (Ivanov and Repina, 2018).

In turn, the subsurface AW in the EGC is fed by the recirculation of the surface water of the WSC, an extension of the Norwegian Atlantic Front Current (NwAFC) and the Norwegian Atlantic Slope Current (NwASC). The recirculation is mostly driven by eddies (Boyd and D'Asaro, 1994; Nilsen et al., 2006; Hattermann et al., 2016). The interannual variations in the vertical mixing intensity between the 
$\mathrm{AW}$, the PW and the modified AW, returning from the Arctic through the southern Fram Strait, as well as variations in ocean-atmosphere exchange in that area, leads to interannual variability of the AW advected by the EGC into the Greenland Sea (Langehaug and Falck, 2012). All the processes intensify during highly dynamic winter conditions. Nevertheless, interannual correlation of the summer upperocean water temperature $(0-200 \mathrm{~m})$, spatially averaged over the MIZ area, with that in the upper WSC is 0.8-0.9. Further south, correlation of interannual variations in the MIZ temperature with that of the NwAFC (NwASC) or with the heat flux across the Svinøy section are low. The decrease is due to damping of the advected heat anomalies in the Norwegian Sea by eddy heat transport and ocean-atmosphere exchange (Asbjørnsen et al., 2019). Besides differences in local forcing, regional atmospheric forcing over the northwestern Barents Sea regulates the interannual variations in the heat redistribution between the WSC and the Barents Sea (Lien et al., 2013), further decreasing the correlations.

Nevertheless, in the long run (over the four most recent decades), temperature at the WSC, the NwAFC, NwASC and the heat flux across Svinøy section all show positive trends (Figs. 4, 5). This is confirmed by a number of studies (Alekseev et al., 2001b; Piechura and Walczowski, 2009; Beszczynska-Möller et al., 2012). The trends form a part of the long-term oscillation of water temperature in the Norwegian Current (Yashayaev and Seidov, 2015).

Pressure fields in the northern North Atlantic are mainly governed by NAO and the East Atlantic patterns (Woollings et al., 2010; Moore and Renfrew, 2012; Foukal and Lozier, 2017). Both patterns affect the wind stress curl, largely regulating ocean circulation in the Nordic Seas. During the positive NAO phase, the cyclonic atmospheric circulation over the Nordic Seas intensifies (Skagseth et al., 2008; Germe et al., 2011). This leads to stronger northerly winds along the Greenland shelf, as well as stronger southerly winds along the Norwegian coast, which results in a more intensive cyclonic oceanic circulation in the Nordic Seas (Schlichtholz and Houssais, 2011). Several regional studies, based on in situ data, demonstrate a higher intensity of oceanic transport of volume and heat along the AW path towards the Fram Strait during the positive NAO phase (Raj et al., 2018; Walczowski, 2010; Chatterjee et al., 2018). Thus, change from strongly negative to strongly positive NAO index (NAOI) results in an increase by $50 \%$ of the NwASC transport as well as increasing the oceanic heat flux (Skagseth et al., 2004, 2008; Raj et al., 2018). We obtained a significant correlation between NAOI and oceanic heat advection with the Norwegian current at Svinøy ( 0.5 for the heat flux integrated over the upper $500 \mathrm{~m}$ layer). The link between the AW transport by the WSC, as well as the cyclonic circulation in the Greenland Sea, and NAO phase is also obtained from observations and numerical models (Walczowski, 2010; Chatterjee et al., 2018). Correlation of NAOI with southward heat flux in the Fram recirculation is also positive but not significant $(0.3)$.
The intensity of the flux may be damped by nonlinear dependence due to the AW entering the recirculation as eddy shedding. Additionally, observations demonstrate that the positive NAO phase drives a stronger ice drift through Fram Strait (Vinje and Finnekåsa, 1986; Koenigk et al., 2007; Giles et al., 2012; Köhl and Serra, 2014), a stronger EGC (Blindheim et al., 2000; Kwok, 2000) and a typically larger extension of Odden ice tongue (Shuchman et al., 1998; Germe et al., 2011). The stronger PW transport also dams the AW anomalies, entering into the study region.

NAO phase is shown to be the main driver for interannual variations in sea ice volume flux to the Greenland Sea (Germe et al., 2011; Ricker et al., 2018). The simultaneous long-term (1974-1997) intensification of the AW inflow in the Nordic Seas across the Faroe-Shetland Ridge and of eastwards advection of PW to the southwestern Norwegian Sea, as a response to NAO forcing, has been noted in several studies (see, for example, Blindheim et al. (2000); Yashayaev and Seidov (2015).

From the beginning of the 1970s, the winter NAO index has been growing. From 1979 to 2016 it was mostly positive (Fig. 7), although an overall winter trend can be separated into an increase from 1979 to 1994, a rapid drop from 1995 to 1996 and an increase from 1996 to 2016. The NAO index drop in 1995-1996 coincides with a drop in regional sea ice volume loss and a decrease in the WSC water temperature (Fig. 4b, d). This can be related to the minimum heat flux through the Svinøy section in 1994 (Fig. 4d). The time needed for water properties to propagate from Svinøy to the Fram Strait with the NwASC is on the order of 1.5-2 years (Walczowski, 2010).

Summer NAO index does not govern the interannual variations in the atmospheric or oceanic systems (circulation in the Nordic Seas intensifies in winter and is thought to bring more AW to the recirculation region compared to that in summer). Consistent with other studies of seasonal interannual variations in current intensity in the region, our results suggest that these are winter variations in the AW transport that bring up the interannual variations in the subsurface water temperature in the MIZ of the Greenland Sea. The decreasing summer NAO index from 1979 may be responsible for a somewhat stronger tendency in the SIV loss in winter compared to summer (Fig. 4a, b).

Summing up, the positive phase of NAO intensifies the whole current system of the Nordic Seas, simultaneously intensifying sea ice flux through Fram Strait and the northward heat flux with the AW to the Nordic Seas. In this paper we demonstrated that the intensification of the AW heat inflow contributes to variations in the sea ice volume in the Greenland Sea. This supplements previous results, showing that the AW inflow dominates the oceanographic conditions over the upper Greenland Sea, except for the shelf area (e.g., Alekseev et al., 2001a; Marnela et al., 2013).

In spite of the stronger ice melt, the upper-ocean salinity in MIZ, as well as along the EGC and in the NwASC, has in- 


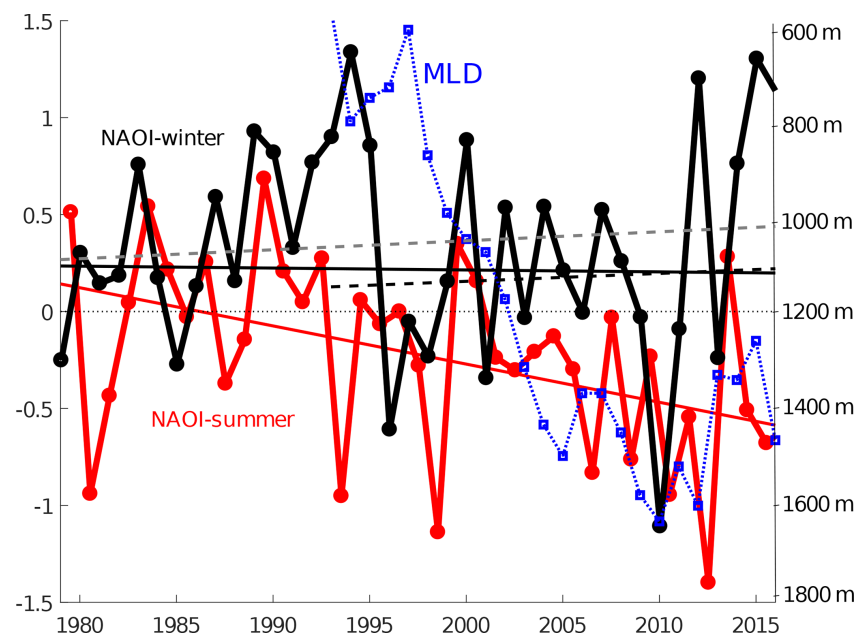

Figure 7. Cold-season NAO index (black, November-April) and warm season NAO index (red, May-October) with linear trends. Additionally plotted are the trends of cold-season NAO index since 1993 (dashed black line, October-April) and for the winter season (dashed gray line, January-April). The blue line shows the maximum MLD in the Greenland Sea derived from the ARMOR dataset (see Bashmachnikov et al., 2019, for details).

creased during recent decades (Fig. 5d). We relate salinification in the MIZ area of the upper Greenland Sea to a stronger flux of the AW and more intensive winter mixing. These effects override the additional freshwater input from the ice melt. Oppositely, during freshening of the upper Greenland Sea, i.e., the Great Salinity Anomaly of 1966-1972, more ice was observed in the MIZ region and the Odden ice tongue was pronounced (Rogers and Hung, 2008). This confirms the reverse relation between the sea ice extent and the MIZ salinity in the Greenland Sea and their dependence on interannual variations in the intensity of the $\mathrm{AW}$ advection.

Another possibly not independent mechanism is linked to the intensity of the deep convection in the Greenland Sea (Fig. 7). A more intense convection, governed by thermohaline characteristics of the upper Greenland Sea, the sea ice extent, and the intensity of ocean-atmosphere heat and freshwater exchange (Marshall and Schott, 1999; Moore et al., 2015), lowers the sea level in the Greenland Sea (Gelderloos et al., 2013; Bashmachnikov et al., 2019). This in turn increases the cyclonic circulation in the region. This effect works together with NAO forcing. Deep convection in the Greenland Sea shows a consistent increase from about $1000 \mathrm{~m}$ in the beginning of the 1990s to about $1500-2000 \mathrm{~m}$ during 2008-2010, after which a certain tendency to decrease is noted (Bashmachnikov et al., 2019). The ongoing increase in salinity of the upper Greenland Sea (Fig. 5d) during the recent decades favors deeper convection (see also Lauvset et al., 2018; Brakstad et al., 2019). Satellite altimetry data show that, during the same period, the area-mean cyclonic vorticity over the Nordic Seas has grown by about $10 \%$. The circulation increase is also consistent with the detected intensification of the AMOC after its minimum in the 1980s (Rahmstorf et al., 2015). However, during the latest decade a stagnation or a possible reversal of the tendency is observed (Smeed et al., 2014).

\section{Conclusions}

Using PIOMAS sea ice volume data, we derived trends in the mean annual, winter, and summer sea ice volume (SIV) in the Greenland Sea and the sea ice volume flux (SIF) through Fram Strait from 1979 to 2016. Taking into account the SIV inflow and outflow through Fram and Denmark Straits, the thermodynamic SIV loss within the Greenland Sea was derived. We found an increase in monthly SIV loss of $9.4 \mathrm{~km}^{3}$ per decade. From 1979 to 2016, the overall SIV loss was $\sim 270 \mathrm{~km}^{3}$, in spite of an increase in SIF of $\sim 280 \mathrm{~km}^{3}$ during the same time period. However, those PIOMAS-based trends should be treated cautiously. The absence of positive anomaly in PIOMAS-based SIF in 1989-1990 indicates that the PIOMAS underestimate thickness of thick sea ice in the Fram Strait and in the Greenland Sea. The biases might lead to a weaker long-term SIF trend, while the SIV trend may be stronger.

Our analysis of the upper-ocean water properties in the marginal sea ice (MIZ) zone of the EGC shows a notable increase in the Atlantic Water (AW) temperature below the pycnocline, as well as of winter mixed-layer depth from 1993 to 2016. These changes result in a higher sea surface heat release, providing twice the amount of the heat needed for bringing up the observed SIV loss. This suggests that the long-term variations in the heat flux entering the Nordic Seas, advected northwards with the NwASC as the AW and further on with the WSC into the MIZ, largely contribute to the corresponding long-term SIV variations in the Greenland Sea. The analysis of marginal sea ice zone (MIZ) ocean parameters showed an increase in mixed-layer depth (MLD) and its temperature from 1993 to 2016 . The estimated amount of additional oceanic heat released from 1993 to 2016 is surplus to the amount of heat necessary for bringing up the observed SIV loss. Therefore, we state that the AW advection into the MIZ largely contributes to the SIV loss. We suggest that the simultaneous tendencies in the long-term increase in SIF and of the AW transport are both linked to a higher intensity of atmospheric circulation during the positive NAO phase.

Data availability. PIOMAS sea ice volume data are available at the Polar Science Center web page (https://pscfiles.apl.uw.edu/zhang/ PIOMAS/data/v2.1/heff/, last access: 1 December 2019) The AWI Cryosat 2 sea ice thickness data are available though the online sea ice knowledge and data platform (https://data.meereisportal. de/, last access: 1 December 2019) The Climatological Atlas of the Nordic Seas and Northern North Atlantic is available at the 
National Oceanographic Data Center (https://www.nodc.noaa.gov/ OC5/nordic-seas/, last access: 1 December 2019).

Author contributions. VS and IB conceptualized the study. VS conducted sea ice data analysis and prepared the manuscript. IB and AV prepared and analyzed the ocean temperature data. RR processed the PIOMAS data and calculated the sea ice volume fluxes. LB supervised the investigation. All co-authors participated in text writing and reviewing.

Competing interests. The authors declare that they have no conflict of interest.

Acknowledgements. We thank Stefan Kern and the anonymous referees for their careful comments that helped improve the paper.

Financial support. This research has been supported by the Russian Science Foundation (RSF) (grant no. 17-17-01151). Igor Bashmachnikov was also supported through a travel grant from the St. Petersburg State University (grant no. 34824520).

Review statement. This paper was edited by David Schroeder and reviewed by two anonymous referees.

\section{References}

Alekseev, G., Johannessen, O., and Kovalevskii, D.: Development of convective motions under the effect of local perturbations of sea-surface density, Izv. Atmos. Ocean. Phy., 37, 341-350, 2001.

Alekseev, G. V., V., B. P., and Nagurnij, A.: Struktura termokhalinnikn polej v rajone tsiklonicheskoj tsirkulatsii i podnyatiya vod, in: Struktura i izmenchivist' krupnomasshtabnyh okeanologicheskih processov i polej v Norvezhskoj energoaktivnoj zone, Gidrometizdat, Leningrad, 18-27, 1989 (in Russian).

Alekseev, G. V., Johannessen, O., and Kovalevsky, D. V.: On development of convective motions under the influence of local density perturbations on the sea surface, Atmos. Ocean Phys., 37, 368-377, 2001a.

Alekseev, G. V., Johannessen, O. M., Korablev, A. A., Ivanov, V. V., and Kovalevsky, D. V.: Interannual variability in water masses in the Greenland Sea and adjacent areas, Polar Res., 20, 201-208, https://doi.org/10.1038/ncomms2505, 2001b.

Arfeuille, G., Mysak, L., and Tremblay, L.-B.: Simulation of the interannual variability of the wind-driven Arctic sea-ice cover during 1958-1998, Clim. Dynam., 16, 107-121, 2000.

Asbjørnsen, H., Årthun, M., Skagseth, Ø., and Eldevik, T.: Mechanisms of ocean heat anomalies in the Norwegian Sea, J. Geophys. Res.-Ocean., 124, 2908-2923, 2019.

Bashmachnikov, I., Fedorov, A., Vesman, A., Belonenko, T., Koldunov, A., and Dukhovskoy, D.: The thermohaline convection in the subpolar seas of the North Atlantic from satellite and in situ observations, Part 1: localization of the deep convection sites, Russian/Sovremennye problemy distantsionnogo zondirovaniya Zemli iz kosmosa, 15, 184-194, https://doi.org/10.21046/2070-7401-2018-15-7-184-194, 2018.

Bashmachnikov, I., Fedorov, A., Vesman, A., Belonenko, T., and Dukhovskoy, D.: The thermohaline convection in the subpolar seas of the North Atlantic from satellite and in situ observations, Part 2: ndices of intensity of deep convection, Russian/Sovremennye problemy distantsionnogo zondirovaniya Zemli iz kosmosa, 16, 191-201, https://doi.org/10.21046/20707401-2019-16-1-191-201, 2019.

Beszczynska-Möller, A., Fahrbach, E., Schauer, U., and Hansen, E.: Variability in Atlantic water temperature and transport at the entrance to the Arctic Ocean, 1997-2010, ICES J. Mar. Sci., 69, 852-863, 2012.

Blindheim, J., Borovkov, V., Hansen, B., Malmberg, S.-A., Turrell, W., and Østerhus, S.: Upper layer cooling and freshening in the Norwegian Sea in relation to atmospheric forcing, Deep-Sea Res. Pt. I, 47, 655-680, 2000.

Bondevik, E.: Studies of Eddies in the Marginal Ice Zone Along the East Greenland Current Using Spaceborne Synthetic Aperture Radar (SAR), Master's thesis, The University of Bergen, 2011.

Boyd, T. J. and D'Asaro, E. A.: Cooling of the West Spitsbergen Current: wintertime observations west of Svalbard, J. Geophys. Res.-Ocean., 99, 22597-22618, 1994.

Brakstad, A., Våge, K., Håvik, L., and Moore, G.: Water mass transformation in the Greenland Sea during the period 1986-2016, J. Phys. Oceanogr., 49, 121-140, 2019.

Buckley, M. W. and Marshall, J.: Observations, inferences, and mechanisms of the Atlantic Meridional Overturning Circulation: A review, Rev. Geophys., 54, 5-63, 2016.

Chatterjee, S., Raj, R. P., Bertino, L., Skagseth, Ø., Ravichandran, M., and Johannessen, O. M.: Role of Greenland Sea Gyre Circulation on Atlantic Water Temperature Variability in the Fram Strait, Geophys. Res. Lett., 45, 8399-8406, https://doi.org/10.1029/2018GL079174, 2018.

Comiso, J. C.: A rapidly declining perennial sea ice cover in the Arctic, Geophys. Res. Lett., 29, 17, https://doi.org/10.1029/2002GL015650, 2002.

Comiso, J. C.: Bootstrap Sea Ice Concentrations from Nimbus7 SMMR and DMSP SSM/I-SSMIS, Version 2, Boulder, Colorado USA, NASA National Snow and Ice Data Center Distributed Active Archive Center, available at: https://nsidc.org/ data/nsidc-0079/ (last access: 18 September 2018), 2015.

Comiso, J. C., Wadhams, P., Pedersen, L. T., and Gersten, R. A.: Seasonal and interannual variability of the Odden ice tongue and a study of environmental effects, J. Geophys. Res.-Ocean, 106, 9093-9116, 2001.

de Boyer Montégut, C., Madec, G., Fischer, A. S., Lazar, A., and Iudicone, D.: Mixed layer depth over the global ocean: An examination of profile data and a profilebased climatology, J. Geophys. Res.-Ocean., 109, C12003, https://doi.org/10.1029/2004JC002378, 2004.

Dukhovskoy, D., Johnson, M., and Proshutinsky, A.: Arctic decadal variability from an idealized atmosphere-ice-ocean model: 2 . Simulation of decadal oscillations, J. Geophys. Res.-Ocean, 111, C08029, https://doi.org/10.1029/2004JC002821, 2006.

Foukal, N. P. and Lozier, M. S.: Assessing variability in the size and strength of the $\mathrm{N}$ orth A tlantic subpolar gyre, J. Geophys. Res.-Ocean., 122, 6295-6308, 2017. 
Gelderloos, R., Katsman, C., and Våge, K.: Detecting Labrador sea water formation from space, J. Geophys. Res.-Ocean., 118, 2074-2086, 2013.

Germe, A., Houssais, M.-N., Herbaut, C., and Cassou, C.: Greenland Sea sea ice variability over 1979-2007 and its link to the surface atmosphere, J. Geophys. Res.-Ocean, 116, C10034, https://doi.org/10.1029/2011JC006960, 2011.

Giles, K., Laxon, S., Ridout, A., Wingham, D., and Bacon, S.: The wind driven spin-up of the Beaufort Gyre from satellite radar altimetry, in: Geophysical Research Abstracts, Vol. 14, EGU201213341, EGU General Assembly, 2012.

Glessmer, M. S., Eldevik, T., Våge, K., Nilsen, J. E. Ø., and Behrens, E.: Atlantic origin of observed and modelled freshwater anomalies in the Nordic Seas, Nat. Geosci., 7, 801-805, 2014.

Guinehut, S., Dhomps, A.-L., Larnicol, G., and Le Traon, P.Y.: High resolution 3-D temperature and salinity fields derived from in situ and satellite observations, Ocean Sci., 8, 845-857, https://doi.org/10.5194/os-8-845-2012, 2012.

Hansen, B., Østerhus, S., Turrell, W. R., Jónsson, S., Valdimarsson, H., Hátún, H., and Olsen, S. M.: The inflow of Atlantic water, heat, and salt to the nordic seas across the Greenland-Scotland ridge, in: Arctic-Subarctic Ocean Fluxes, Springer, 15-43, 2008.

Hattermann, T., Isachsen, P. E., von Appen, W.-J., Albretsen, J., and Sundfjord, A.: Eddy-driven recirculation of Atlantic water in Fram Strait, Geophys. Res. Lett., 43, 3406-3414, https://doi.org/10.1002/2016GL068323, 2016.

Håvik, L., Pickart, R. S., Våge, K., Torres, D., Thurnherr, A. M., Beszczynska-Möller, A., Walczowski, W., and von Appen, W.J.: Evolution of the East Greenland current from Fram Strait to Denmark strait: synoptic measurements from summer 2012, J. Geophys. Res.-Ocean., 122, 1974-1994, 2017.

Hendricks, S., Ricker, R., and Helm, V.: User GuideAWI CryoSat-2 Sea Ice Thickness Data Product (v1. 2), hdl:10013/epic.48201.d001, 2016.

Ivanov, V. and Repina, I.: The Effect of Seasonal Variability on the State of the Arctic Sea Ice Cover, Izvestiya rossiyskoy akademii nauk, Fizika atmosfery i okeana, 54, 73-82, https://doi.org/10.7868/S0003351518010087, 2018

Jeansson, E., Jutterström, S., Rudels, B., Anderson, L. G., Olsson, K. A., Jones, E. P., Smethie Jr, W. M., and Swift, J. H.: Sources to the East Greenland Current and its contribution to the Denmark Strait Overflow, Prog. Oceanogr., 78, 12-28, 2008.

Jeansson, E., Olsen, A., and Jutterström, S.: Arctic intermediate water in the Nordic Seas, 1991-2009, Deep-Sea Res. Pt. I, 128, 8297, 2017.

Kara, A. B., Rochford, P. A., and Hurlburt, H. E.: Mixed layer depth variability over the global ocean, J. Geophys. Res.-Ocean., 108, 3079, https://doi.org/10.1029/2000JC000736, 2003.

Kern, S., Kaleschke, L., and Spreen, G.: Climatology of the Nordic (Irminger, Greenland, Barents, Kara and White/Pechora) Seas ice cover based on $85 \mathrm{GHz}$ satellite microwave radiometry: 19922008, Tellus A, 62, 411-434, 2010.

Koenigk, T., Mikolajewicz, U., Haak, H., and Jungclaus, J.: Arctic freshwater export in the 20th and 21st centuries, J. Geophys. Res.-Biogeo., 112, G04S41, https://doi.org/10.1029/2006JG000274, 2007.

Köhl, A. and Serra, N.: Causes of decadal changes of the freshwater content in the Arctic Ocean, J. Clim., 27, 3461-3475, 2014.
Korablev, A., Pnyushkov, A., and Smirnov, A.: Compiling of the oceanographic database for climate monitoring in the Nordic Seas, Russian/Trudy AARI, 447, 85-108, 2007.

Kwok, R.: Recent changes in Arctic Ocean sea ice motion associated with the North Atlantic Oscillation, Geophys. Res. Lett., 27, 775-778, 2000.

Kwok, R. and Rothrock, D. A.: Variability of Fram Strait ice flux and North Atlantic Oscillation, J. Geophys. Res.-Ocean., 104, 5177-5189, https://doi.org/10.1029/1998JC900103, 1999.

Kwok, R., Cunningham, G., and Pang, S.: Fram Strait sea ice outflow, J. Geophys. Res.-Ocean., 109, C01009, https://doi.org/10.1029/2003JC001785, 2004.

Langehaug, H. R. and Falck, E.: Changes in the properties and distribution of the intermediate and deep waters in the Fram Strait, Prog. Oceanogr., 96, 57-76, 2012.

Latarius, K. and Quadfasel, D.: Seasonal to inter-annual variability of temperature and salinity in the Greenland Sea Gyre: heat and freshwater budgets, Tellus A, 62, 497-515, 2010.

Latarius, K. and Quadfasel, D.: Water mass transformation in the deep basins of the Nordic Seas: Analyses of heat and freshwater budgets, Deep-Sea Res. Pt. I, 114, 23-42, 2016.

Lauvset, S. K., Brakstad, A., Våge, K., Olsen, A., Jeansson, E., and Mork, K. A.: Continued warming, salinification and oxygenation of the Greenland Sea gyre, Tellus A, 70, 1-9, 2018.

Lien, V. S., Vikeb $\varnothing$, F. B., and Skagseth, Ø.: One mechanism contributing to co-variability of the Atlantic inflow branches to the Arctic, Nat. Commun., 4, 1488, https://doi.org/10.1038/ncomms2505, 2013.

Lindsay, R. and Zhang, J.: The thinning of Arctic sea ice, 19882003: Have we passed a tipping point?, J. Clim., 18, 4879-4894, 2005.

Marnela, M., Rudels, B., Houssais, M.-N., Beszczynska-Möller, A., and Eriksson, P. B.: Recirculation in the Fram Strait and transports of water in and north of the Fram Strait derived from CTD data, Ocean Sci., 9, 499-519, https://doi.org/10.5194/os-9-4992013, 2013.

Marshall, J. and Schott, F.: Open-ocean convection: Observations, theory, and models, Rev. Geophys., 37, 1-64, 1999.

Marshall, J., Kushnir, Y., Battisti, D., Chang, P., Czaja, A., Dickson, R., Hurrell, J., McCartney, M., Saravanan, R., and Visbeck, M.: North Atlantic climate variability: phenomena, impacts and mechanisms, Int. J. Climatol., 21, 1863-1898, 2001.

Maslanik, J., Fowler, C., Stroeve, J., Drobot, S., Zwally, J., Yi, D., and Emery, W.: A younger, thinner Arctic ice cover: Increased potential for rapid, extensive sea-ice loss, Geophys. Res. Lett., 34, L24501, https://doi.org/10.1029/2007GL032043, 2007.

Meereisportal: AWI Cryosat 2 sea ice thickess data, available at: https://data.meereisportal.de/, last access: 1 December 2019.

Meincke, J., Jonsson, S., and Swift, J. H.: Variability of convective conditions in the Greenland Sea, ICES Mar. Sci. Symp, 195, 32 39, 1992.

Moore, G. and Renfrew, I.: Cold European winters: interplay between the NAO and the East Atlantic mode, Atmos. Sci. Lett., $13,1-8,2012$.

Moore, G. W. K., Våge, K., Pickart, R. S., and Renfrew, I. A.: Decreasing intensity of open-ocean convection in the Greenland and Iceland seas, Nat. Clim. Change, 5, 877-882, https://doi.org/10.1038/nclimate2688, 2015. 
Moretskij, V. N. and Popov, A.: Vodnye massy Norvezhskogo i Grenlandskogo morej i osnovnye tipy vertikalnogoj stuktury vod, in: Struktura i izmenchivist' krupnomasshtabnyh okeanologicheskih processov i polej v Norvezhskoj energoaktivnoj zone, Gidrometizdat, Leningrad, 18-27, 1989 (in Russian).

Mulet, S., Rio, M.-H., Mignot, A., Guinehut, S., and Morrow, R.: A new estimate of the global 3D geostrophic ocean circulation based on satellite data and in-situ measurements, Deep-Sea Res. Pt. II, 77, 70-81, 2012.

National Oceanographic Data Center: Climatological Atlas of the Nordic Seas and Northern North Atlantic, available at: https:// www.nodc.noaa.gov/OC5/nordic-seas/, last access: 1 December 2019.

Nilsen, F., Gjevik, B., and Schauer, U.: Cooling of the West Spitsbergen Current: Isopycnal diffusion by topographic vorticity waves, J. Geophys. Res.-Ocean., 111, C08012, https://doi.org/10.1029/2005JC002991, 2006.

Onarheim, I. H., Eldevik, T., Smedsrud, L. H., and Stroeve, J. C.: Seasonal and regional manifestation of Arctic sea ice loss, J. Clim., 31, 4917-4932, 2018.

Peterson, B. J., McClelland, J., Curry, R., Holmes, R. M., Walsh, J. E., and Aagaard, K.: Trajectory shifts in the Arctic and subarctic freshwater cycle, Science, 313, 1061-1066, 2006.

Petrich, C. and Eicken, H.: Growth, structure and properties of sea ice, Sea Ice, 2, 23-77, 2010.

Pickart, R. S., Torres, D. J., and Clarke, R. A.: Hydrography of the Labrador Sea during active convection, J. Phys. Oceanogr., 32, 428-457, 2002.

Piechura, J. and Walczowski, W.: Warming of the West Spitsbergen Current and sea ice north of Svalbard, Oceanologia, 51, 147-164, https://doi.org/10.5697/oc.51-2.147, 2009.

Polar Sciense Center: PIOMAS sea ice volume data, available at: https://pscfiles.apl.uw.edu/zhang/PIOMAS/data/v2.1/ heff/, last access: 1 December 2019.

Rahmstorf, S., Box, J. E., Feulner, G., Mann, M. E., Robinson, A., Rutherford, S., and Schaffernicht, E. J.: Exceptional twentieth-century slowdown in Atlantic Ocean overturning circulation, Nat. Clim. Change, 5, 475-480, https://doi.org/10.1038/nclimate2554, 2015.

Raj, R. P., Nilsen, J. Ø., Johannessen, J., Furevik, T., Andersen, O., and Bertino, L.: Quantifying Atlantic Water transport to the Nordic Seas by remote sensing, Remote Sens. Environ., 216, 758-769, https://doi.org/10.1016/j.rse.2018.04.055, 2018.

Rhein, M., Kieke, D., and Steinfeldt, R.: Advection of $\mathrm{N}$ orth A tlantic D eep W ater from the L abrador S ea to the southern hemisphere, J. Geophys. Res.-Ocean., 120, 2471-2487, 2015.

Ricker, R., Hendricks, S., Helm, V., Skourup, H., and Davidson, M.: Sensitivity of CryoSat-2 Arctic sea-ice freeboard and thickness on radar-waveform interpretation, The Cryosphere, 8, 16071622, https://doi.org/10.5194/tc-8-1607-2014, 2014.

Ricker, R., Hendricks, S., Kaleschke, L., Tian-Kunze, X., King, J., and Haas, C.: A weekly Arctic sea-ice thickness data record from merged CryoSat-2 and SMOS satellite data, The Cryosphere, 11, 1607-1623, https://doi.org/10.5194/tc-11-1607-2017, 2017.

Ricker, R., Girard-Ardhuin, F., Krumpen, T., and Lique, C.: Satellite-derived sea ice export and its impact on Arctic ice mass balance, The Cryosphere, 12, 3017-3032, https://doi.org/10.5194/tc-12-3017-2018, 2018.
Rigor, I. G. and Wallace, J. M.: Variations in the age of Arctic seaice and summer sea-ice extent, Geophys. Res. Lett., 31, L09401, https://doi.org/10.1029/2004GL019492, 2004.

Rogers, J. C. and Hung, M.-P.: The Odden ice feature of the Greenland Sea and its association with atmospheric pressure, wind, and surface flux variability from reanalyses, Geophys. Res. Lett., 35, L08504, https://doi.org/10.1029/2007GL032938, 2008.

Rudels, B., Fahrbach, E., Meincke, J., Budéus, G., and Eriksson, P.: The East Greenland Current and its contribution to the Denmark Strait overflow, ICES J. Mar. Sci., 59, 1133-1154, 2002.

Schlichtholz, P. and Houssais, M.-N.: Forcing of oceanic heat anomalies by air-sea interactions in the Nordic Seas area, J. Geophys. Res.-Ocean., 116, C01006, https://doi.org/10.1029/2009JC005944, 2011.

Schweiger, A., Lindsay, R., Zhang, J., Steele, M., Stern, H., and Kwok, R.: Uncertainty in modeled Arctic sea ice volume, J. Geophys. Res.-Ocean., 116, C00D06, https://doi.org/10.1029/2011JC007084, 2011.

Serreze, M. C., Barrett, A. P., Slater, A. G., Woodgate, R. A., Aagaard, K., Lammers, R. B., Steele, M., Moritz, R., Meredith, M., and Lee, C. M.: The large-scale freshwater cycle of the Arctic, Geophys. Res.-Ocean., 111, C11010, https://doi.org/10.1029/2005JC003424, 2006.

Shuchman, R. A., Josberger, E. G., Russel, C. A., Fischer, K. W., Johannessen, O. M., Johannessen, J., and Gloersen, P.: Greenland Sea Odden sea ice feature: Intra-annual and interannual variability, J. Geophys. Res.-Ocean., 103, 12709-12724, 1998.

Skagseth, Ø., Orvik, K. A., and Furevik, T.: Coherent variability of the Norwegian Atlantic Slope Current derived from TOPEX/ERS altimeter data, Geophys. Res. Lett., 31, L14304, https://doi.org/10.1029/2004GL020057, https://doi.org/10.1029/2004GL020057, 2004.

Skagseth, Ø., Furevik, T., Ingvaldsen, R., Loeng, H., Mork, K. A., Orvik, K. A., and Ozhigin, V.: Volume and heat transports to the Arctic Ocean via the Norwegian and Barents Seas, in: ArcticSubarctic Ocean Fluxes, Springer, 45-64, 2008.

Smedsrud, L. H., Halvorsen, M. H., Stroeve, J. C., Zhang, R., and Kloster, K.: Fram Strait sea ice export variability and September Arctic sea ice extent over the last 80 years, The Cryosphere, 11, 65-79, https://doi.org/10.5194/tc-11-65-2017, 2017.

Smeed, D. A., McCarthy, G. D., Cunningham, S. A., FrajkaWilliams, E., Rayner, D., Johns, W. E., Meinen, C. S., Baringer, M. O., Moat, B. I., Duchez, A., and Bryden, H. L.: Observed decline of the Atlantic meridional overturning circulation 2004 2012, Ocean Sci., 10, 29-38, https://doi.org/10.5194/os-10-292014, 2014.

Spreen, G., Kern, S., Stammer, D., and Hansen, E.: Fram Strait sea ice volume export estimated between 2003 and 2008 from satellite data, Geophys. Res. Lett., 36, L19502, https://doi.org/10.1029/2009GL039591, 2009.

Sumata, H., Lavergne, T., Girard-Ardhuin, F., Kimura, N., Tschudi, M. A., Kauker, F., Karcher, M., and Gerdes, R.: An intercomparison of A rctic ice drift products to deduce uncertainty estimates, J. Geophys. Res.-Ocean., 119, 4887-4921, 2014.

Sumata, H., Gerdes, R., Kauker, F., and Karcher, M.: Empirical error functions for monthly mean Arctic sea-ice drift, J. Geophys. Res.-Ocean., 120, 7450-7475, 2015.

Tschudi, M., Fowler, C., Maslanik, J., Stewart, J. S., and Meier, W. N.: Polar Pathfinder Daily $25 \mathrm{~km}$ EASE-Grid Sea Ice Mo- 
tion Vectors, Version 3, Boulder, Colorado USA. NASA National Snow and Ice Data Center Distributed Active Archive Center, available at: https://nsidc.org/data/nsidc-0116/versions/3 (last access: 18 September 2018), 2016.

Våge, K., Moore, G. W. K., Jónsson, S., and Valdimarsson, H.: Water mass transformation in the Iceland Sea, Deep-Sea Res. Pt. I, 101, 98-109, 2015.

Våge, K., Papritz, L., Håvik, L., Spall, M. A., and Moore, G. W. K.: Ocean convection linked to the recent ice edge retreat along east Greenland, Nat. Commun., 9, 1287, https://doi.org/10.1038/s41467-018-03468-6, 2018.

Vinje, T. and Finnekåsa, Ø.: The ice transport through the Fram Strait, Norsk Polarinstitutt, Oslo, Rep. 186, 39 pp., 1986.

Vinje, T., Nordlund, N., and Kvambekk, Å.: Monitoring ice thickness in Fram Strait, J. Geophys. Res.-Ocean., 103, 10437-10449, 1998.

Visbeck, M., Fischer, J., and Schott, F.: Preconditioning the Greenland Sea for deep convection: Ice formation and ice drift, J. Geophys. Res.-Ocean., 100, 18489-18502, 1995.

von Appen, W.-J., Wekerle, C., Hehemann, L., SchourupKristensen, V., Konrad, C., and Iversen, M. H.: Observations of a Submesoscale Cyclonic Filament in the Marginal Ice Zone, Geophys. Res. Lett., 45, 6141-6149, https://doi.org/10.1029/2018GL077897, 2018.

Wadhams, P., Comiso, J., Prussen, E., Wells, S., Brandon, M., Aldworth, E., Viehoff, T., Allegrino, R., and Crane, D.: The development of the Odden ice tongue in the Greenland Sea during winter 1993 from remote sensing and field observations, J. Geophys. Res.-Ocean., 101, 18213-18235, 1996.
Wadhams, P., Budéus, G., Wilkinson, J., Løyning, T., and Pavlov, V.: The multi-year development of long-lived convective chimneys in the Greenland Sea, Geophys. Res. Lett., 31, L06306, https://doi.org/10.1029/2003GL019017, 2004.

Walczowski, W.: Atlantic Water in the Nordic Seas-properties, variability, climatic significance, Oceanologia, 52, 325-327, https://doi.org/10.1007/978-3-319-01279-7, 2010.

Warren, S. G., Rigor, I. G., Untersteiner, N., Radionov, V. F., Bryazgin, N. N., Aleksandrov, Y. I., and Colony, R.: Snow depth on Arctic sea ice, J. Clim., 12, 1814-1829, 1999.

Woollings, T., Hannachi, A., and Hoskins, B.: Variability of the North Atlantic eddy-driven jet stream, Q. J. Roy. Meteor. Soc., 136, 856-868, 2010.

Yashayaev, I. and Seidov, D.: The role of the Atlantic Water in multidecadal ocean variability in the Nordic and Barents Seas, Prog. Oceanogr., 132, 68-127, 2015.

Ypma, S., Brüggemann, N., Georgiou, S., Spence, P., Dijkstra, H., Pietrzak, J., and Katsman, C.: Pathways and watermass transformation of Atlantic Water entering the Nordic Seas through Denmark Strait in two high resolution ocean models, Deep-Sea Res. Pt. I, 145, 59-72, https://doi.org/10.1016/j.dsr.2019.02.002, 2019.

Yu, Y., Maykut, G., and Rothrock, D.: Changes in the thickness distribution of Arctic sea ice between 1958-1970 and 1993-1997, J. Geophys. Res.-Ocean., 109, C08004, https://doi.org/10.1029/2003JC001982, 2004.

Zhang, J. and Rothrock, D.: Modeling global sea ice with a thickness and enthalpy distribution model in generalized curvilinear coordinates, Mon. Weather Rev., 131, 845-861, 2003. 